\title{
ALVORADA DO REMO: MEMÓRIA, CIDADE E IMAGENS
}

\author{
Cristhian Caje ${ }^{1}$
}

Alex Vailati ${ }^{2}$

O trabalho que segue elabora uma reflexão sobre os processos de construção de narrativas sobre a memória e a história do remo em Florianópolis, capital do Estado de Santa Catarina, a partir da introdução e do incentivo desse esporte durante a primeira metade do século XX. Para tal, foi analisada a exposição fotográfica intitulada " $A$ História em 100 anos. Homenagem a todos que dignificaram as cores riachuelinas", construída, musealizada e exposta nos salões do centenário Clube Náutico Riachuelo, pelos próprios riachuelos durante o ano de 2015. Essa exposição se insere dentro de um conjunto de atividades comemorativas pelo centenário da fundação do Clube Náutico Riachuelo, como agremiação esportiva mais antiga de Florianópolis, que se mantém ativa atualmente.

Consideramos as atividades decorrentes deste calendário de comemorações um marco para a identidade dos remadores riachuelinos. A construção da exposição fotográfica significou um "evento", no sentido empregado por Sahlins (1999), na sua clássica Ilha de Histórias ${ }^{3}$, pensando-a numa categoria analítica para um ocorrido culturalmente significado, que não tem data de validade e que tem o poder de driblar a imaginação das pessoas. O evento, como o descreve Sahlins, nos faz pensar, ele tensiona a nossa compreensão do nosso lugar. Diferente dos fatos cotidianos, por exemplo, um evento é um marco temporal dentro da cultura.

As formas culturais tradicionais abarcavam o evento extraordinário e recriavam as distinções dadas de status, com o efeito de reproduzir a cultura da forma que estava constituída. As condições específicas do contato europeu deram origem a formas de oposição entre chefia e pessoas comuns que não estavam previstas nas relações tradicionais. No mundo ou na açãotecnicamente, em atos de referência- categorias culturais adquirem novos valores funcionais. (Sahlins, 1987: 174).

\footnotetext{
${ }^{1}$ Universidade Federal de Santa Catarina, Brasil. Email: cristhiancaje@gmail.com ORCID id: https://orcid.org/0000-0002-8713-7872

2 Universidade Federal de Pernambuco, Brasil. Email: alexvailati@gmail.com ORCID id: https://orcid.org/0000-0002-4851-4815

${ }^{3}$ SAHLINS, Marshall. Ilhas de História, Jorge Zahar Editor Rio de Janeiro, 1999.
} 
A construção dessa exposição surge a partir do desejo e do esforço pessoal de um dos remadores mais velho do clube, Seu Décio. Ele é considerado pelos seus pares como detentor do status de "guardião da memória". Guardião, como uma metáfora de quem luta contra o esquecimento. O exercício da recordação entre os riachuelinos foi possível por seus esforços e mérito, que mobilizou, coletou fotografias, iconografias, cartas e objetos do seu acervo pessoal, familiar, e as juntou ao acervo de outras de famílias que mantêm vínculos próximos e tradicionais com esta instituição, para, posteriormente, expô-las pelas paredes da cozinha do clube. $\mathrm{Na}$ Imagem $\mathbf{N}^{\mathbf{0}} \mathbf{1}$, está Seu Décio ao lado dos seus painéis. Foi ele quem organizou a ordem das imagens e as colocou emolduradas. As pessoas contavam sobre o carinho e o empenho do Seu Décio nessa hora, que tomava café no Clube Náutico Riachuelo, antes de retomar um trabalho que exige zelo. Um jornal local fez uma cobertura desse evento e descreveu o seu trabalho como segue:

Com um pouco de dificuldade, as mãos que fizeram parte da história do remo catarinense colavam fotografias no painel de 100 anos do clube, o primeiro da Capital a atingir a marca centenária. Fundado em 11 de junho de 1915, o Riachuelo é 50 dias mais antigo que o Martinelli, que faz 100 anos no dia 31 de julho - o Aldo Luz é de 27 de dezembro de 1918. Jornal ND, publicado em 2 de setembro de 2016.

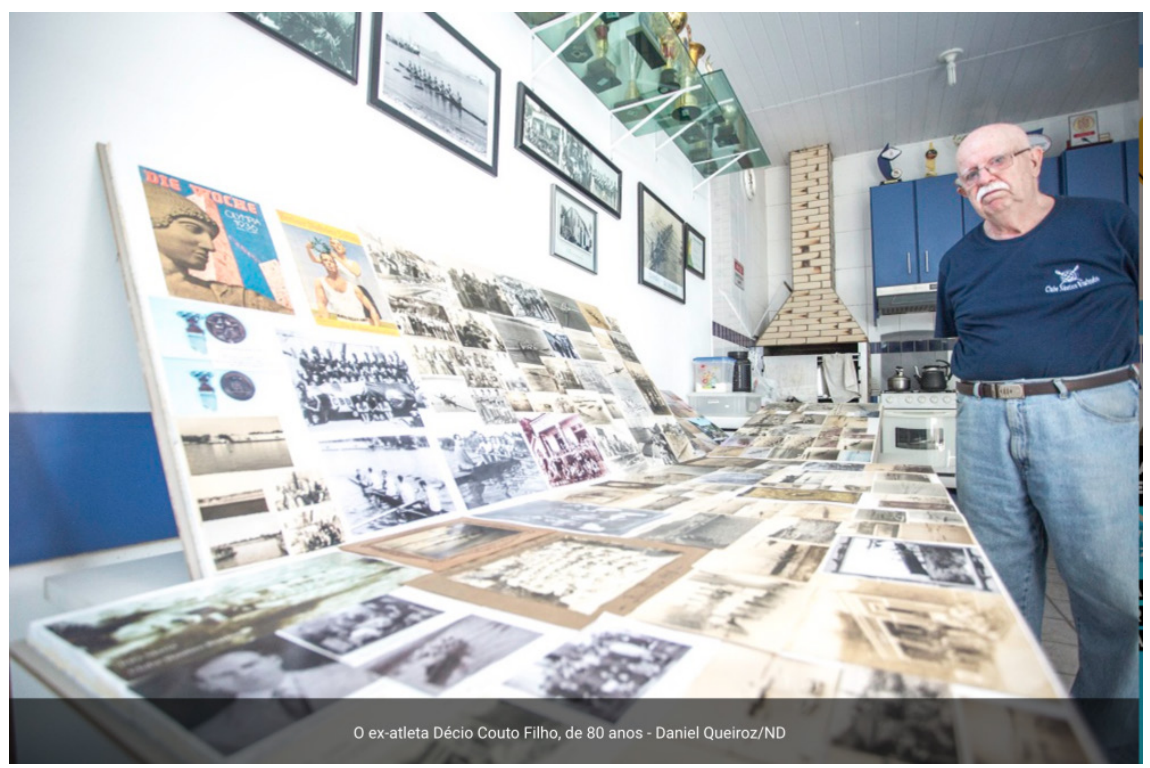

Imagem No 1: Seu Décio e os painéis fotográficos.

(Acervo do Jornal ND, publicado em 2 de setembro de 2016, acessado em agosto de 2019) 
A Imagem $\mathbf{N}^{\mathbf{0}} \mathbf{2}$, mostra o espaço onde foram colocados os painéis. A cozinha é o lugar de sociabilidade mais importante dentro do Clube Riachuelo, é onde os atletas se reúnem para descansar e comer algo depois do treino, o lugar onde a diretoria semanalmente realiza suas reuniões e também é o lugar onde os mais velhos se juntam toda sexta-feira para os jogos de mesa e para conversar sobre as memórias do passado e do presente. As fotografias que decoram as paredes os enchem de orgulho e cada um deles tem uma anedota que as ilustra. A história do remo em Florianópolis, construída ao longo do século dentro da água, hoje é compartilhada entre amigos durante as reuniões que acontecem nesse lugar, entre uma partida e outra de xadrez ou baralho. São como fragmentos de memória de cada um dos ex-remadores que hoje compõem a diretoria do clube. Fragmentos que se misturam e se fundem não apenas em uma verdade sobre as façanhas dos barcos, mas em várias versões da mesma narrativa que, por vezes, contradizem-se ou complementam-se.

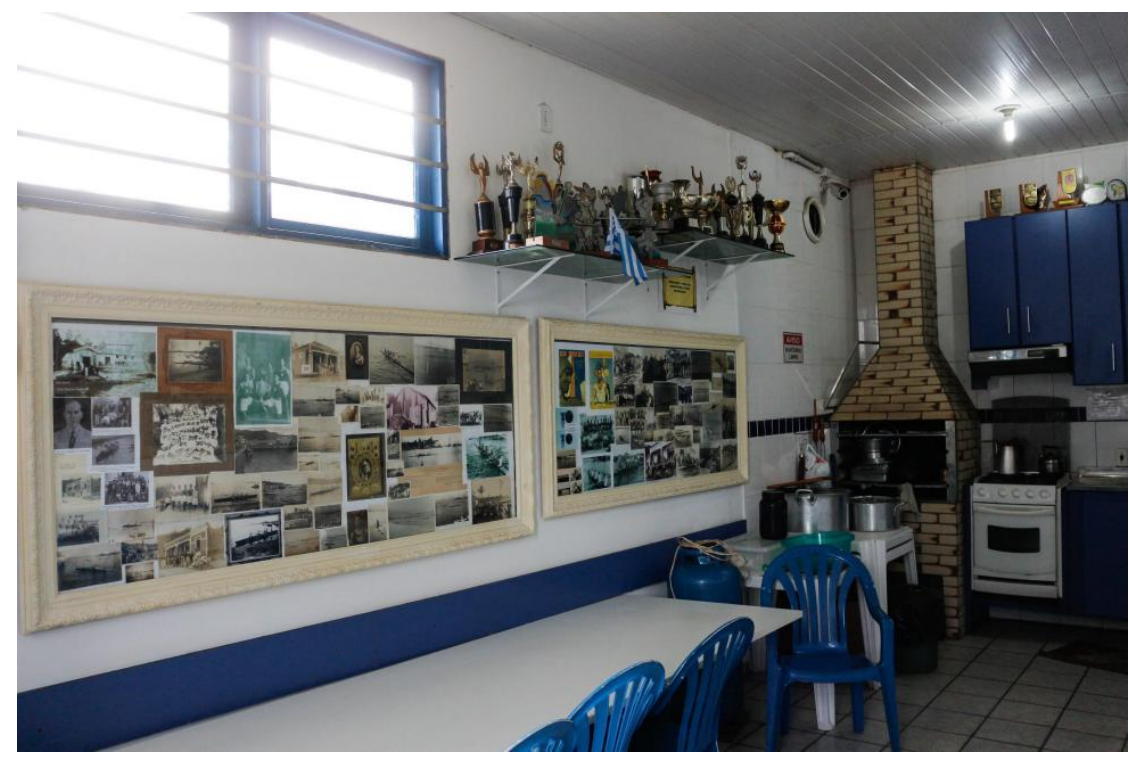

Imagem $\mathbf{N}^{\circ}$ 2: Painéis fotográficos pendurados nas paredes da cozinha do clube. (Registro do meu acervo pessoal. Agosto de 2018)

O ex-atleta de mais de 80 anos, entre uma foto e outra, viaja no tempo e relembra, emocionado, passagens da época de ouro do remo:

"A ideia é fazer com que a história do remo catarinense não se perca. Daqui a pouco, não estaremos mais aqui para contá-la. Eu sempre esperei por este momento, não sabia se viveria para isso. Alguns bons amigos partiram desta vida antes, como o Sadi, que morreu este ano, mas nós estamos aqui firmes e fortes para celebrar estes 100 anos".

Mas, Seu Décio não é somente mais um remador da sua geração. A lembrança 
mais destacada que guarda na memória remete ao pai já falecido, Décio Klettenberg Couto, timoneiro e único catarinense a disputar os Jogos Olímpicos de Berlim, em 1936. No mesmo ano, junto com a guarnição ${ }^{4}$ de Santa Catarina, representada pelos atletas do Riachuelo, conquistou o primeiro título brasileiro de remo do Estado, em Salvador, na Bahia, o que lhe rendeu o direito de representar o Brasil na Olimpíada. Na Imagem $\mathbf{N}^{\mathbf{0}} \mathbf{3}$, encontramos uma fotografia de seu pai, em destaque dentro do conjunto das demais imagens, carregando consigo todas as medalhas que lhe foram atribuídas nas suas várias conquistas. Isso outorga a Seu Décio uma ascendência linear familiar que lhe garante o status de guardião da memória. Ao mesmo tempo, o clube também constrói um lugar de destaque em sua homenagem, como vemos na Imagem $\mathbf{N}^{0} 4$.

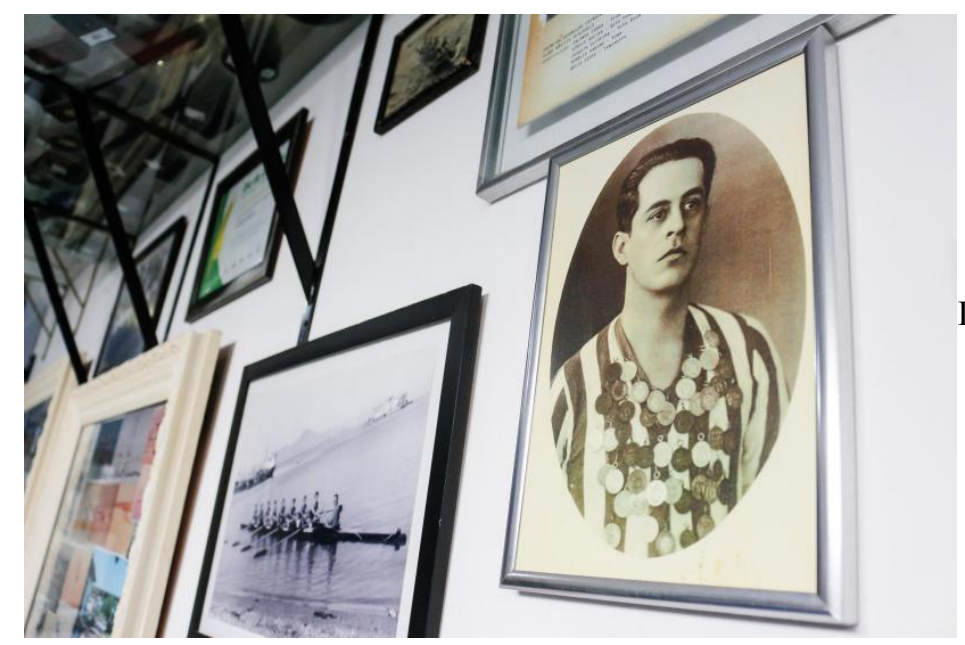

Imagem $N^{0}$ 3: Retrato de Décio Klettenberg Couto. (Registro do meu acervo pessoal. Agosto de 2018)

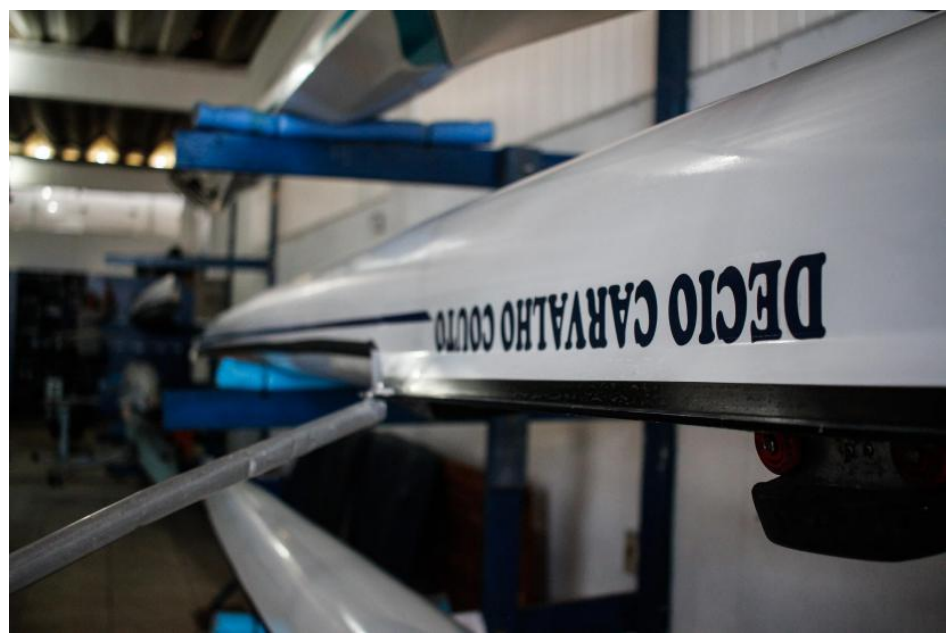

Imagem $\mathbf{N}^{0}$ 4: Skiff batizado com o nome de Décio Carvalho Couto. (Registro do meu acervo pessoal. Agosto de 2018)

\footnotetext{
${ }^{4}$ Essa é uma palavra que tem origem no vocábulo militar e que se usa para nomear um conjunto de tropas destacadas para determinado local. Os riachuelinos utilizam-na para se referir aos conjuntos de atletas que compõem a equipe de um barco.
} 


\section{O ACERVO COMO NARRADOR}

A partir das fotografias que compunham os painéis elaborados por Seu Décio, realizamos algumas análises sobre elementos que foram emergindo de forma imagética e que organizam as narrativas sobre a origem do passado, a emergência da cidade de Florianópolis, em contraposição à antiga vila Nossa Senhora do Desterro e o avanço da terra sobre o mar. Essas narrativas, presentes na temporalidade que as imagens fazem, foram ganhando centralidade e força durante o decorrer das atividades que envolveram a comemoração do centenário do clube.

Para nossa análise, levamos em conta a dimensão ambígua da memória, para a qual Candau (2002) aponta. De um lado, o exercício da lembrança - que aparece nas partes superficiais, iluminadas ou oficiais dessas narrativas, na medida em que são compartilhadas. De outro, o do esquecimento ou da amnésia - em que é possível analisar os aspectos mais opacos ou menos óbvios delas, na medida em que são caladas ou apagadas. Ao mesmo tempo, observamos que existem dinâmicas de transformação cultural em um evento como esse. Sua relação com a história remete a algumas discussões sobre história e cultura que surgiram na antropologia a partir de autores como Marshall Sahlins (1987), Lilia Schwarcz (2005) e Jean e John Comaroff (2016), que caracterizam essa dinâmica pela continuidade e mudança, simultaneamente.

A metodologia de leitura de imagens que optamos para este trabalho, proposta por Schwarcz $(2004)^{5}$, permitiu-nos estabelecer alguns pontos para nossa análise. Primeiro: observar como, a partir da temporalização que as imagens fazem, é possível identificar essas narrativas sobre a memória e a história, permitindo entender como a identidade dos riachuelinos emerge, se tenciona-se, se fragmenta e se recria 100 anos após a fundação do clube. Segundo: não se trata de incluir as fotografias para enfatizar ou ilustrar as análises, mas de mostrá-las como documentos com agência própria, que constroem modelos e concepções de mundo para os remadores - por isso, optamos por introduzi-las ao longo do texto em um tamanho considerável -, ou seja, não como

\footnotetext{
${ }^{5}$ SCHWARCZ, Lilia. Lendo e agenciando imagens: o rei, a natureza e seus belos naturais. Sociologia e Antropologia, Rio de janeiro, v.04.02: 391 - 431, outubro, 2014.
} 
reflexos, mas como a produção de representações, costumes, percepções. Não como imagens fixas e presas nas molduras, mas como objetos que circulam, interpelam e negociam identidade e memória (Schwarcz, 2014: 393).

Empregamos o termo "representação", no sentido de "estar em lugar de, e atuar por”, para, assim, tornar possível uma relação maior entre texto e imagem e menos como meros registros imediatos de seu momento. As fotografias e objetos da exposição que analisaremos ajudaram a formar percepções coletivas entre os remadores, criando conceitos difundidos da realidade. Essas imagens ganharam centralidade dentro do espaço do clube e até fora, por conta da divulgação da mídia local. Para nós, elas são o narrador principal para as análises, ajudando-nos no exercício da compreensão da história, da memória e da identidade do remo, esboçando sua presença e suas relações com a cidade e as elites políticas e intelectuais da capital catarinense ao longo do século $\mathrm{XX}$, assim como nos permitiram visualizar fragmentos dos "tempos áureos" do Riachuelo, bem como dos lugares urbanos já habitados por eles em Florianópolis.

\section{ONDE COMEÇA O PASSADO?}

Nossa chegada ao Clube Náutico Riachuelo, em março de 2015, coincidiu com o começo das comemorações do centenário dos clubes de remo da cidade. Fundado no dia 11 de julho de 1915, o Riachuelo colecionou êxitos ao longo de sua história e foi o primeiro clube de remo catarinense a participar de uma olimpíada, em 1936, na Alemanha. Havia entre eles muita expectativa pelo aniversário número cem, já que nele havia promessas de renovação, de visibilidade e de festa. Muitos deles definiram esse sentimento com a palavra "alegria". Loreno, presidente do clube em exercício naquele ano, definiu esse momento durante um discurso dizendo as seguintes palavras: "Temos um passado de glórias, mas olhamos para um futuro de paz".

Podemos definir os riachuelinos como pessoas a favor do tempo, a favor da história ou, dito de outra forma, sujeitos que encontraram um lugar muito confortável entre a memória e a história para se apresentar como parte de um discurso identitário que tem a história como elemento fundante. Eles gostam de se pensar como sujeitos vindo de um passado glorioso ou, como os introduz a primeira estrofe do hino do clube: "os vencedores cheios de glória". Esses discursos sobre o passado ficariam mais evidentes ainda com a chegada de junho. Seu Décio, que havia sido convidado para uma homenagem na Assembleia Legislativa de Santa Catarina - ALESC, declarou em seu 
discurso que participa do clube há 70 anos e aguardou com ansiedade a comemoração do centenário:

"É pelo espírito de fidelidade às nossas convicções que estamos sendo homenageados, e com este mesmo espírito devemos continuar a irradiar o exemplo a ser seguido pelas futuras gerações. Minha maior qualidade foi acreditar neste sonho por mais de 70 anos."

Mas, o que era possível fazer com a história, da forma como eles a apresentavam, desde a antropologia? É difícil estabelecer ou delimitar onde começa uma e onde acaba a outra. A história - que estava na fala dos meus interlocutores - era um modelo de causa e efeito, que conta um século depois de outro século. Enfim, é uma forma ocidental de narrá-la, que responde a um padrão. Então, até onde vai o passado para os riachuelinos? Essa contagem cronológica do passado está estreitamente ligada à construção de uma narrativa identitária. Narrativa essa que, se projetada na imagem de um relógio, com as compilações e datas pré determinadas, contava os fatos de maneira sucessiva e seriada, construindo uma certa hierarquia entre os fatos.

Tomamos como um exemplo a entoação do hino ${ }^{6}$ do clube em dias de regatas, que performa um conjunto de tradições e rituais cotidianamente reproduzidos ${ }^{7}$. Podemos elaborar uma interpretação, através dessa entoação, como um documento de atuação que nos permite indagar qual a importância, o que está sendo transmitido como $\mathrm{o}$ ato de içar a bandeira, enquanto entoam a letra. Esses momentos tornam visíveis as ideias de um passado glorioso, descritas por Seu Décio e representadas nas inúmeras fotografias, um passado muito presente, ou, como diria Levis-Strauss, de um presente repleto de passado:

"Nos nossos remos; Impera a força, brilha a vitória. Em nosso peito rebrilha; Toda a grandeza de nossa história. Nos nossos remos; Fulgura a força, brilha a história. Nós queremos é vencer; Nós queremos é remar"

Essa estrofe traz na sua composição a alegoria de um evento repleto de elementos da primeira República, uma referência indireta aos feitos da batalha do Riachuelo, ocorrida durante a guerra contra o Paraguai. Narra o esforço, a luta e o

\footnotetext{
${ }^{6}$ O hino do Clube Náutico Riachuelo foi publicado pela primeira vez no Jornal O Estado de 21 de fevereiro de 1919 (Sartori, 2013: 72)

${ }^{7}$ As regatas são competições náuticas de velocidade entre várias barcos - à vela, a motor ou a remos -, fazendo um percurso assinalado por balizas (bóias) e definidos pelos competidores.
} 
espírito dos riachuelinos quando partem mar adentro e representa, em tom épico, o ideal de entusiasmo que os atletas devem demonstrar durante as competições. A estrofe elabora um paralelismo entre o êxito histórico e o êxito esportivo e representa a vitória como característica atávica de um grupo. As conquistas que ocorreram outrora na história seriam aquelas que reapareciam em "brilho" e "força" como elemento distintivo. Pelos paralelos estabelecidos ao longo da estrofe, "remar" e "vencer" são construídos nos últimos versos como sinônimos, como duas expressões de um mesmo feito.

A palavra "história", que é reiterada, aparece como uma metáfora dela mesma. De um lado, aquele adjetivo abstrato que organiza os acontecimentos e as datas importantes de maneira cronológica; de outro, um elemento que impulsiona, dá força e legitima um discurso no presente. Como uma performance atual dos tempos idos das grandes batalhas de barcos, ela ressignifica uma identidade saudosista e, sob o olhar etnográfico de quem pretende elaborar uma descrição densa sobre esse grupo, essa estrofe contém um acúmulo de símbolos valiosos, sendo possível inseri-la em uma teia de significados, conforme proposto por Geertz (1989) em sua concepção de uma análise semiótica da cultura, conferindo-lhe esse sentido essencialmente semiótico, de conhecimento público e compartilhado.

Mas, vamos um pouco mais atrás no passado ou um pouco mais à frente na nossa análise. Com o surgimento do remo como prática esportiva, que remonta aos acontecimentos decorrentes da Revolução Industrial, em meados do século XIX, entre a França e a Inglaterra, entre a prática do rowing $^{8}$ e do canotage $^{9}$, ele se insere dentro de um conjunto de outros esportes chamados atléticos, que se aproximavam de outras práticas físicas, como a ginástica, a dança e seus movimentos aos jogos diversos.

\footnotetext{
${ }^{8}$ Segundo o historiador Henrique Licht, no livro $O$ remo através dos tempos (1986), foi em 1825 que tiveram início na Universidade de Cambridge, as regatas estudantis entre alunos de seus diferentes colégios. Um ano mais tarde, a prática do remo e as competições se multiplicavam na Inglaterra, particularmente entre estudantes e universitários. Em 1827, a Fundação do Cambridge University Boat Club realizou sua primeira regata em 09/12/1828. Em Oxford, o remo continuou a ser disputado entre alunos de seus diversos colégios. Neste ano, ocorreu o segundo destaque na história do remo britânico e mundial: a realização da primeira prova entre barcos a oito remos, das universidades de Oxford e Cambridge.

${ }^{9} \mathrm{Na}$ França, a prática do remo se encontraria com a prática do canotage, uma atividade citadina e experimental que propunha um rompimento com o trabalho e com o tempo cotidiano na Paris de meados do século XIX (Sartori, 2013: 29). Nesse contexto, o Remo aparece como incentivo ao desenvolvimento físico e como formação para homens jovens, proporcionando uma educação para o trabalho em grupo junto à ideia de competição saudável. Os primeiros barcos eram de porte pesado e com velas, contando com a presença do canotier. Amadores e 'amantes' das construções náuticas passariam a calcular o tempo e as distâncias para adaptar as embarcações a uma melhor velocidade e tempo.
} 
Durante os primeiros anos do século XX, o movimentar-se esportivo tornou-se técnico, rigoroso e ordenado. É a vez do treino cronometrar as formas e as práticas dos barcos para o alcance máximo do corpo.

Decorrente desse contexto histórico e político, o remo atingiu um lugar de destaque dentro de um conjunto de valores morais, éticos e humanistas de culto ao corpo e à mente propagados pela modernidade, criando, posteriormente, dimensões extracontinentais que se estenderam por toda Europa e chegariam às novas repúblicas das Américas. Autores como Norbert Elias (1992), Eric Dunning (1992) e Pierre Bourdieu (1983), só para citar alguns dos mais importantes intelectuais do campo dos estudos das práticas esportivas, apontam para o surgimento da modernidade como a sociogênese do conceito "esporte", incluindo aqui as práticas náuticas. No seu clássico ensaio Como é possível ser Esportivo ${ }^{10}$, Bourdieu (1983) trata de desmembrar essa relação entre esporte e modernidade, levantando uma questão sobre as condições históricas e sociais desse fenômeno social que, segundo ele, passamos a aceitar como algo óbvio. Para ele, o esporte tem uma história relativamente autônoma que, mesmo que estando articulada com os grandes acontecimentos da história econômica e política, tem seu próprio tempo, suas próprias leis de evolução, suas próprias crises, em suma, é possível elaborar uma cronologia específica? (Bourdieu, 1983, pág. 2).

Fazendo referência ao trabalho da historiadora catarinense Carina Sartori (2013) ${ }^{11}$, a palavra Alvorada, contida no título deste trabalho, envolve esses dois sentidos: o primeiro, remete à hora em que a "guapa rapaziada" encontrava-se para exercitar o físico nos galpões localizados na Beira Mar; o segundo, pelo remo ser um esporte estreitamente vinculado aos projetos políticos da modernidade, àqueles novos homens, àquelas novas cidades - tanto em Paris, em Londres, quanto no Brasil - Rio de Janeiro, Rio Grande do Sul e Florianópolis. A modernidade ligava esses novos conceitos estéticos que envolveram, em sua conjuntura, transformações nos corpos e na vida urbana das grandes cidades, através de práticas incentivadas, de forma a atingir a civilizada vida saudável de cuidado do corpo.

$\mathrm{Na}$ Imagem $\mathbf{N}^{\mathbf{0}} 5$ e 6, aparecem duas fotografias que dialogam e possibilitam perceber como esses conceitos estéticos, que envolvem o corpo e a cidade, circulavam

\footnotetext{
${ }^{10}$ Exposição introdutória ao Congresso Internacional do HISPA, realizado no INSEP (Paris), março de 1978. In: BOURDIEU, Pierre. 1983. Questões de sociologia. Rio de Janeiro: Marco Zero. p 136-153.

${ }^{11}$ SARTORI, Carina. Na alvorada de um sport: o remo na ilha de Santa Catarina. 2003. Dissertação Mestrado, Universidade Federal de Santa Catarina, Centro de Filosofia e Ciências Humanas - Programa de pós-graduação em História.
} 
entre a capital do país, Rio de Janeiro e a capital do Estado, Florianópolis. Em ambas, as fotografias reproduzem a mesma prática e o anúncio de um campeonato brasileiro na fotografia superior deixa clara a evidência que o local a ser imitado, isto é, o detentor do status civilizador era o Rio de Janeiro.
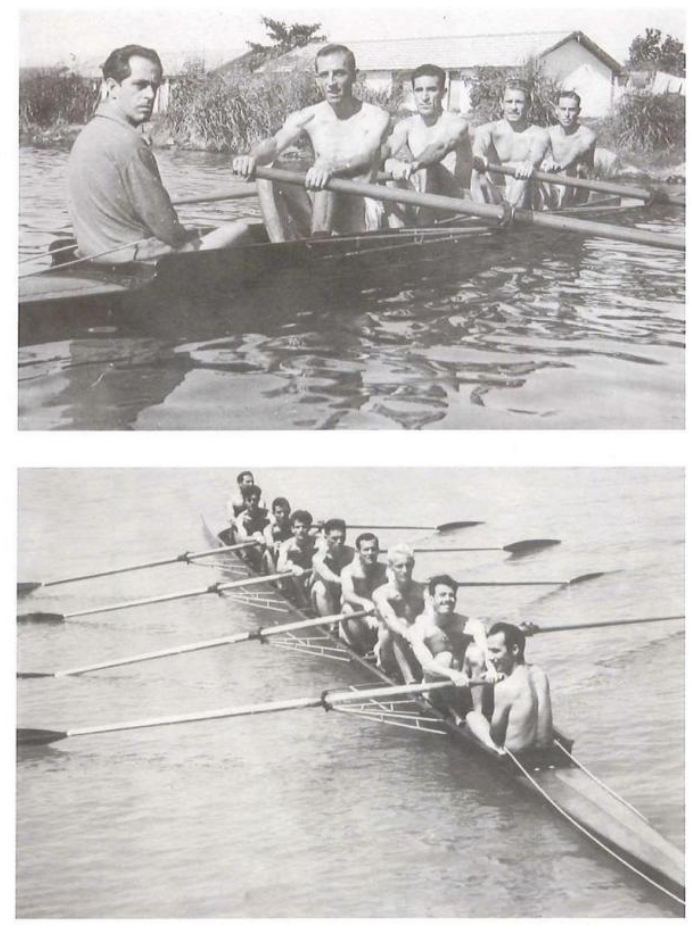

Imagem $\mathbf{N}^{\circ}$ 5: Barco 4 Com, no Campeonato Brasileiro, Rio de Janeiro, 1945. (Acervo do Clube Náutico Riachuelo)

Imagem No 6: Guarnição Campanha Catarinense de 1956. (Acervo do Clube Náutico Riachuelo)

No Brasil, o remo foi o berço de todos os esportes nacionais com a formação dos primeiros clubes esportivos, compostos, na sua grande maioria, por imigrantes lusos e alemães, ajudando a consolidar novos conceitos advindos com os novos tempos. $\mathrm{O}$ remo deu surgimento aos modernos clubes de futebol e outros esportes (Licht, 1986, Sartori, 2013, Melo, 1999, 2000, 2015). Em Florianópolis, sua prática começou a ser desenvolvida entre as baías Norte e Sul, estabelecendo-se no antigo bairro do Rita Maria - perto do atual terminal rodoviário -, uma vez que a formação rochosa e sua extensa praia da região se adequavam perfeitamente à necessidade, como mostra a Imagem $\mathbf{N}^{\mathbf{0}}$ 7.

Nessa imagem, também é possível ver os habitantes de Florianópolis reunidos em torno da chegada dos primeiros barcos. É possível também perceber a presença das elites políticas presentes na cena do remo, desde seus primórdios, que se basearam na efervescência da modernidade crescente e constante entre a população das camadas 
econômicas mais altas para investir num projeto de ordem e progresso. A localização do remo na região da Rita Maria está inteiramente ligada aos anseios dessa elite, composta em sua maioria pelos comerciantes mais ricos do centro e membros do exército, que viam nele um exercício simbólico dos valores da modernidade e associavam-no às inovações sociais da capital federal e a consolidação da participação da alta sociedade na vida política, na nova República.

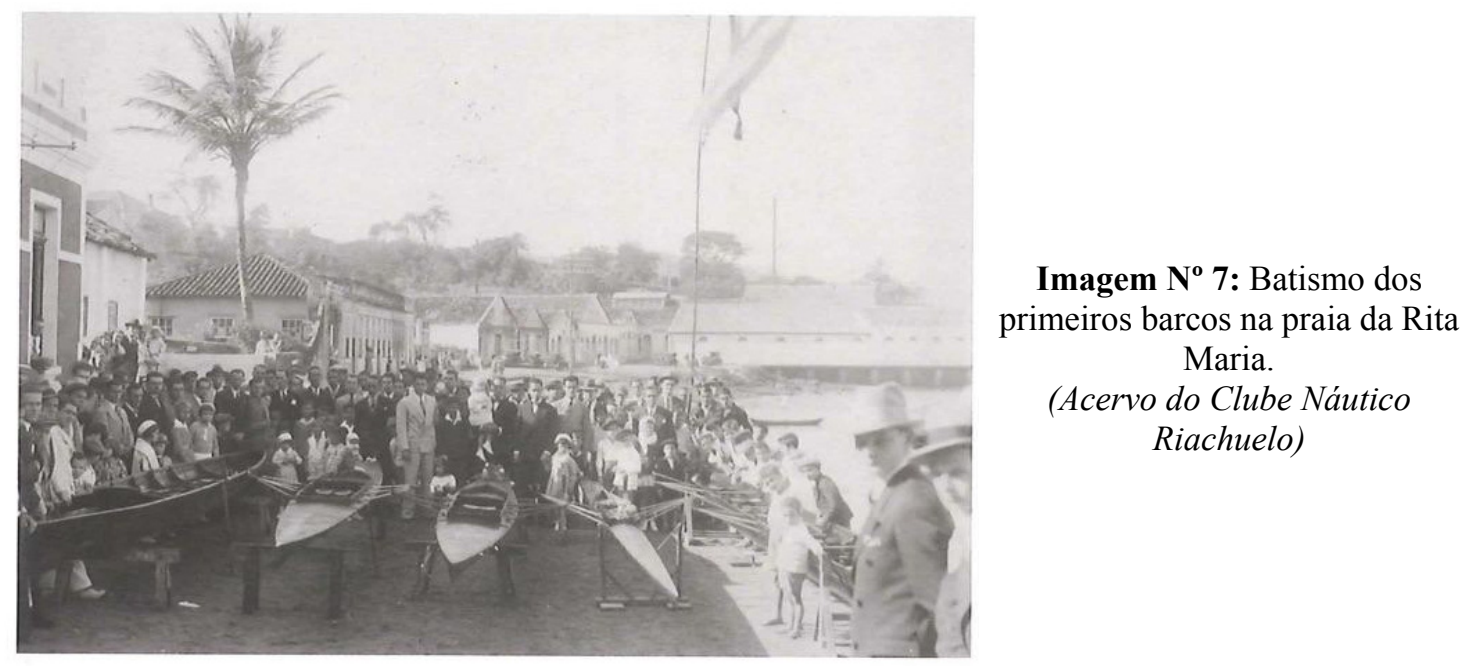

Na Imagem No 8, aparece a legenda: "Onde tudo começou" e faz referência ao primeiro galpão do Clube Náutico Riachuelo. Nela, visualiza-se ainda o mar chegando à porta dos galpões, como se fosse um rastro visível, uma linha divisória habitada pelos barcos que se perderia mais tarde com a chegada do aterro que, com ares expansionistas, traria o esquecimento definitivo, inexorável, da memória coletiva dos remadores mais jovens sobre os limites entre a terra e o mar.

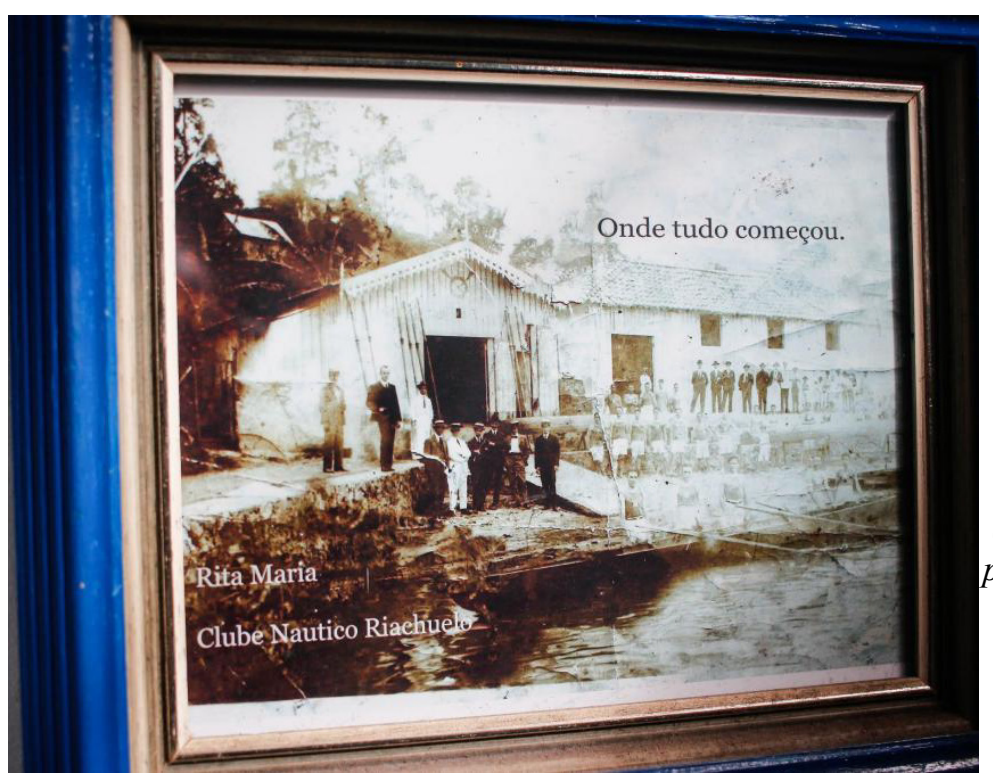

Imagem $\mathbf{N}^{0}$ 8: Onde tudo começou. (Registro do meu acervo pessoal. Agosto de 2018) 
Loreno, que foi o dirigente do Clube Náutico Riachuelo em 2015, enquanto fazíamos o trabalho de campo, assim descreveu sua relação com a região do Rita Maria:

Nós, do Bairro Rita Maria, temos uma relação umbilical com o nosso Riachuelo. Hoje eu entendo aquela dedicação que muitos riachuelinos (in memoriam) tinham pelo nosso clube já que morávamos do lado deste e a nossa relação com o remo era cotidiana. Minha geração as dos 1960's viveu as alegrias das vitórias e a tristeza das derrotas como um sentimento que fazia parte das suas vidas. Todos os transtornos que aconteciam durante os treinos eram compartilhados pela turma. Parecia que o mundo era restrito à nossa rua, Trapiche do Hoepcke, Ilha do Carvão, Fábrica de Prego e de Gelo, Ponte Hercílio Luz e Praia do Rita Maria.

Na Imagem $\mathbf{N}^{\mathbf{0}}$ 9, aparece novamente o galpão de um outro ângulo, deixando visível sua estrutura precária em madeira, lembrando-nos dos ranchos de pesca e do fato que essas primeiras competições entre barcos foram realizadas em uma Florianópolis, essencialmente, dependente do mar para a locomoção e a pesca como subsistência.

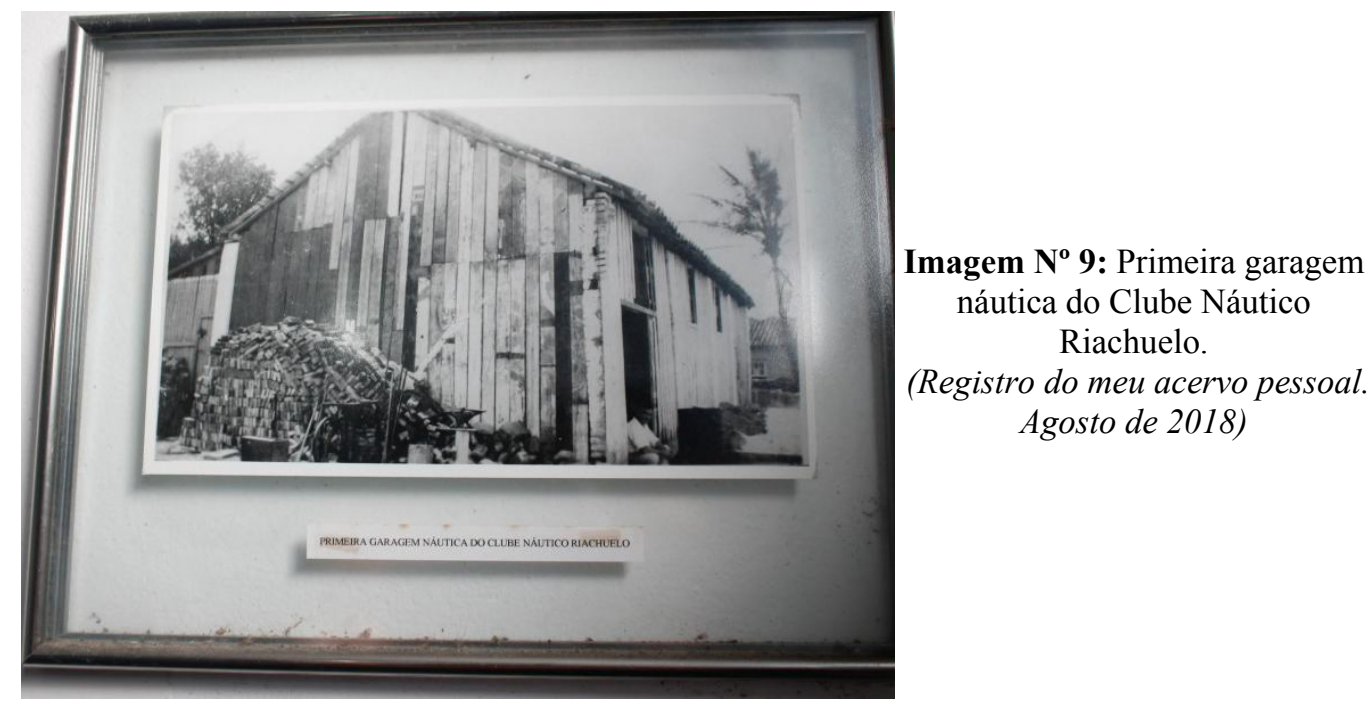

\section{OS NOMES E O REMO}

Nomes, como defende o escritor Jorge Luis Borges, citado por Foucault (2000) em A palavra e as coisas, são carregados de significações históricas. O nome introduz uma convenção social. Conforme observa Lévi-Strauss (1976), no Pensamento Selvagem, nós primeiro damos o nome, depois encontramos sentidos para ele. Existe uma lógica da modernidade por detrás dos nomes que se relacionam ao surgimento do remo na ilha.

Em meados da década de 1880, enquanto Florianópolis ainda era chamada de 
Desterro $^{12}$, destacava-se na capital do Império como um importante centro exportador de farinha de mandioca e, como cidade portuária, era um ponto de desembarque e circulação para os novos habitantes. Havia um incentivo por parte do Império para a imigração europeia, principalmente de alemães e de italianos que chegavam até a pequena vila Nossa Senhora do Desterro. Esse nome, apesar de ser uma referência à fuga da sagrada família para o Egito, desagradava certos moradores, uma vez que lembrava "desterrado" ${ }^{13}$, ou seja, alguém que está no exílio ou que era preso e mandado para um lugar desabitado.

Essa falta de gosto pelo nome fez com que algumas votações acontecessem para uma possível mudança. Uma das sugestões foi a de "Ondina", nome de uma deusa da mitologia que protege os mares, porém, logo foi descartado. Até que, com o fim da Revolução Federalista, em 1894, em homenagem ao então presidente da República Floriano Peixoto, o governador do Estado, Hercílio Luz, mudou o nome para Florianópolis. A escolha do nome foi, contudo, uma afronta à própria população desterrense, dado que Desterro era uma cidade fortemente monarquista e contrária à Proclamação da República. Floriano Peixoto não era uma autoridade com popularidade na cidade e enfrentou grande resistência de seu governo em Desterro.

A nova Florianópolis (1894) passaria, então, a ser remodelada a partir dos novos anseios da elite local em ascensão, com as novas práticas econômicas advindas com a República. Os funcionários públicos, os pequenos proprietários, os profissionais autônomos, os comerciários e os bacharéis, além de buscar diferenciarem-se socialmente das camadas menos privilegiadas da população, também redesenharam as posturas citadinas, de forma a constituir um ar mais "agradável e sadio" "14 que afastasse o significado negativo atribuído ao homem litorâneo de Santa Catarina (Neckel, 2003: 54). Engenheiros, escritores, críticos, poetas, políticos e jornalistas formariam uma geração de produtores de um saber local. Iniciava-se uma era nova na capital, o projeto

\footnotetext{
${ }^{12}$ Em 1514 os portugueses chegaram nesta região, e em 1526 os espanhóis. Apesar de tantas visitas ilustres, o povoamento oficial apenas ocorreu em 1673, e cinco anos mais tarde se construiu uma capela à Nossa Senhora Do Desterro, e daí seu primeiro nome - Desterro. Apenas em 1726 foi elevada à condição de vila, e em 1823 se converteu na capital da província de Santa Catarina.

13 A vasta obra do médico e antropólogo Oswaldo Rodrigues (1903-1978) se debruça sobre a história de Desterro e sobre as disputas pelos nomes ver: Santa Catarina: História e Evolução, de 1937. Nossa Senhora do Desterro, de 1971, editada pela Imprensa Oficial da Universidade Federal de Santa Catarina, consiste em trabalho de fôlego em quatro volumes: Notícia I e II e Memória I e II. Notícia.

${ }^{14}$ NECKEL, R. Op Cit., 2003. p.54. KUPKA, Roselane Neckel. Tensões e imagens do viver urbano em Florianópolis - 1910/1930. Dissertação (Mestrado em História), CFH, UFSC, Florianópolis, 1993.; NECKEL, R. Op. Cit., 2003.
} 
da modernidade chegava em barcos até o porto para se instalar e transformar tudo quanto podia em um reflexo da capital do Império.

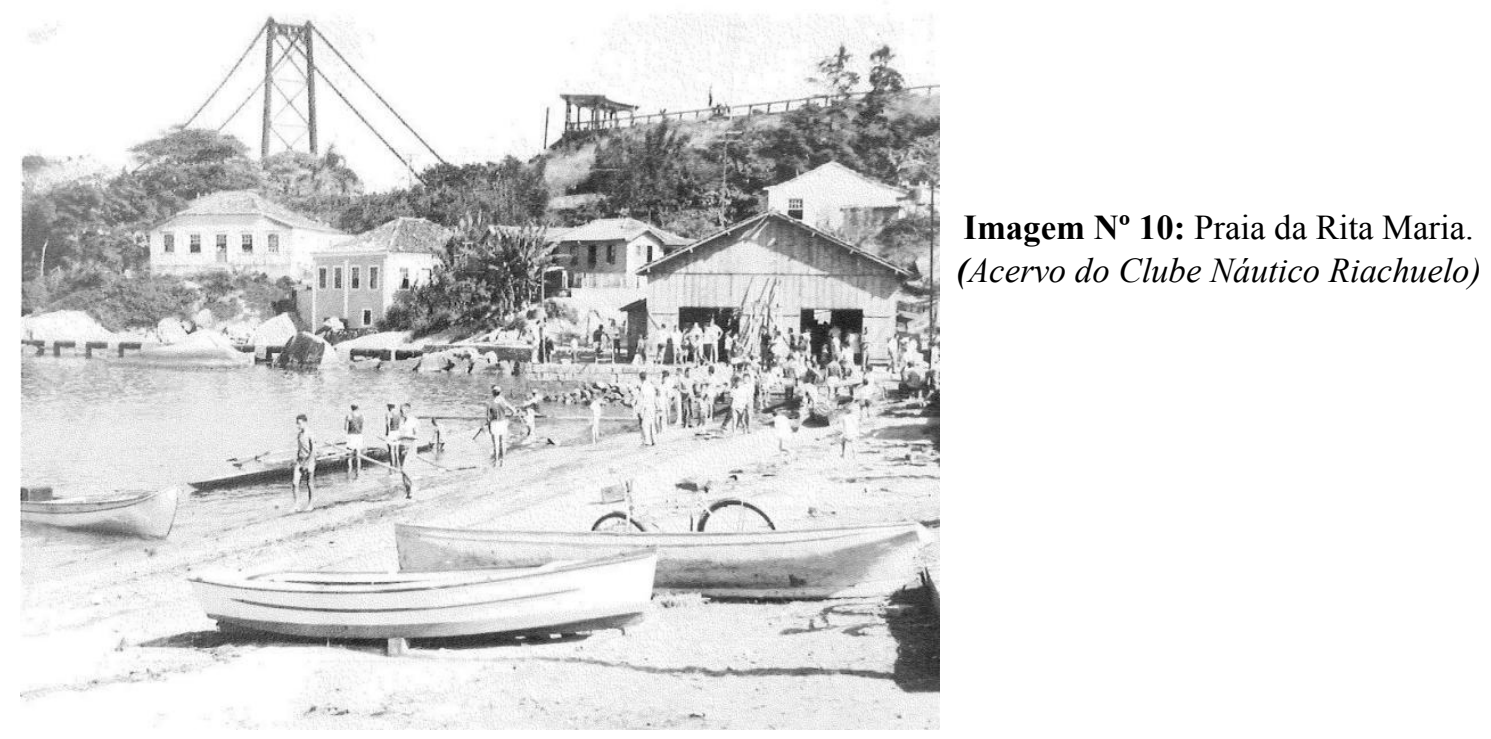

$\mathrm{Na}$ Imagem $\mathbf{N}^{\mathbf{0}}$ 10, na Praia da Rita Maria, aparece claramente esse contraste estético do período de transição entre Império e República. De um lado, ao fundo da fotografia, a ponte Hercílio Luz, símbolo da modernidade advinda com a nova configuração política do país. De outro, num primeiro plano, os galpões dos clubes de remo, no início dos anos de 1920, ainda mostrando a relação estreita com a vida litorânea. Esse período de transição intensificou as discussões sobre a necessidade de modificar o panorama topográfico e social da capital catarinense e, com isso, afastar a imagem da "antiga Vila", associada ao atraso, fazendo surgir a "moderna e civilizada" cidade (Neckel, 2003: 54) ${ }^{15}$.

Como parte desse empreendimento modernizador, de transformação da vida social, começaram os incentivos às primeiras competições de barcos que acabaram gerando, no ano de 1902, no dia 29 de abril, a fundação da primeira agremiação náutica, o Clube de Regatas 29 de Abril. Foi um grupo de homens, formado em sua maioria por generais do exército da marinha, comerciantes, e políticos, que inauguraram junto com o clube a prática organizada e esportiva do remo. Na Imagem $\mathbf{N}^{\mathbf{0}} \mathbf{1 1}$, podemos ver uma cena das primeiras competições promovidas pelo novo clube. Em junho de 1902, aconteceu a primeira competição e teve como homenageado o $37^{\circ}$ aniversário da

15 NECKEL, Roselane. A República em Santa Catarina: Modernidade e exclusão (1889-1920). Florianópolis: Ed. da UFSC, 2003. p.54. 
Batalha Naval do Riachuelo ${ }^{16}$ e, apesar do fechamento brusco do clube, quatro anos mais tarde, seu surgimento suscitaria indagações sobre a presença do esporte na Ilha de Santa Catarina.

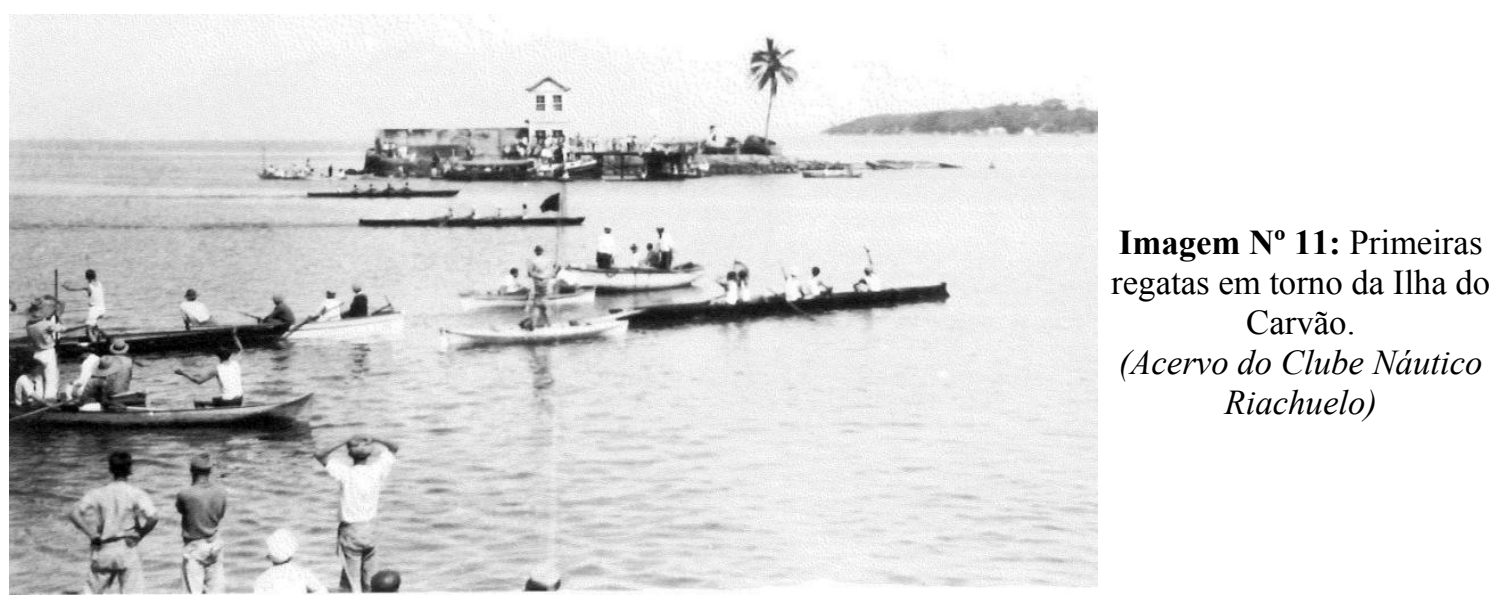

$\mathrm{Na}$ virada do século $\mathrm{XX}$, as atividades relacionadas ao remo eram oferecidas a todos que se associavam ao Clube 29 de Abril. Apesar de uma existência breve - durou quatro anos -, deixaria a prática do remo de volta à forma irregular, com embarcações não apropriadas. Pela primeira vez, a experiência das competições organizadas, e não mais exclusivamente vinculados aos marinheiros ou à Marinha, mas com a sociedade florianopolitana conseguindo correr nos páreos, com equipes formadas e com embarcações e remadores associados a um clube, deixariam aos habitantes com um certo gosto pela modernidade. O clube fechou sem deixar posse do estatuto ou da ata de fundação, por terem sido perdidos ou por nunca terem sido votados por completo. Não se tem maiores dados para argumentar se havia o objetivo de tornar-se um formador de homens modernos, de homens competitivos ou apenas de ser recreativo (Sartoro, 2013: 72).

\footnotetext{
${ }^{16}$ A Batalha Naval do Riachuelo, ou simplesmente Batalha do Riachuelo, travou-se a 11 de junho de 1865, às margens do arroio Riachuelo, um afluente do rio Paraná, na província de Corrientes, na Argentina. Essa é considerada pelos historiadores militares como uma das mais importantes batalhas da Guerra do Paraguai que aconteceu entre os anos de 1864 e 1870.
} 


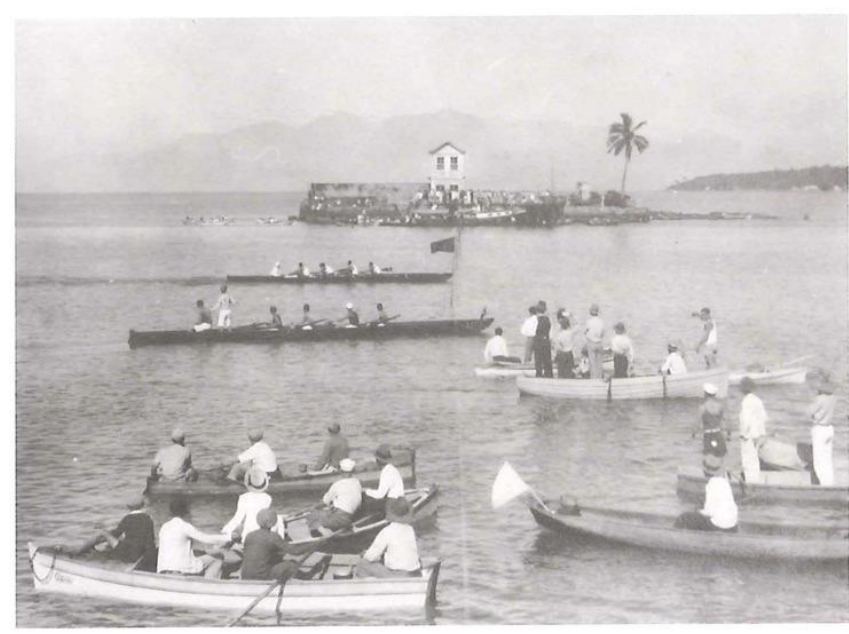

Imagem No 12: Regatas em torno da Ilha do Carvão. (Acervo do Clube Náutico Riachuelo)

Nas Imagens $\mathbf{N}^{0}$ 11, 12 e 13, aparece ao fundo a extinta ilha do Carvão. Essa é uma paisagem que se consagrou na memória fotográfica dos riachuelinos e está presente em quase todas as imagens de competições daquela época. A ilha do Carvão era uma referência de localização das raias que partiam da praia da Rita Maria. Ela é lembrada pelo poeta catarinense Fábio Bruggemann ${ }^{17}$ a partir da figura do esquecimento, como segue:

[...] Cheguei sem procurar. Foi pelo espelho do cartão-postal que atravessei os dias velhos e, ao final, cheguei à Ilha do Carvão, a terra de suposição no mar estreito da Baía Sul.

Ela era a meseta de pedra que surgia na linha de água, no fundo das fotografias, a meio mundo entre a ponte Hercílio Luz e os estaleiros da Hoepcke. Usavam-na para armazenar, no Castelo térreo, as cargas negras, combustíveis e carbonárias. Usavam-na para abastecer, no mar, o vapor dos navios e resguardar de incêndios o cais Rita Maria.

Chamavam-na, entre dentes, de ilha dos ratos. Era a ilha de despensa. Mas quem a visse distante - desde a Ilha das Vinhas ou desde a orla do Mercado Público - adivinharia as suas coordenadas: ela ficava entre dois esquecimentos. Exatamente. Foi uma utopia tímida, ela, ilha-carvoeira tomada de imatéria. [...]

\footnotetext{
${ }^{17}$ Link do Curta-metragem de Fábio Brüggemann e Dennis Radúnz sobre o desaparecimento da Ilha do Carvão disponível no youtube: https://www.youtube.com/watch?v=zN6MZytXQxM
} 


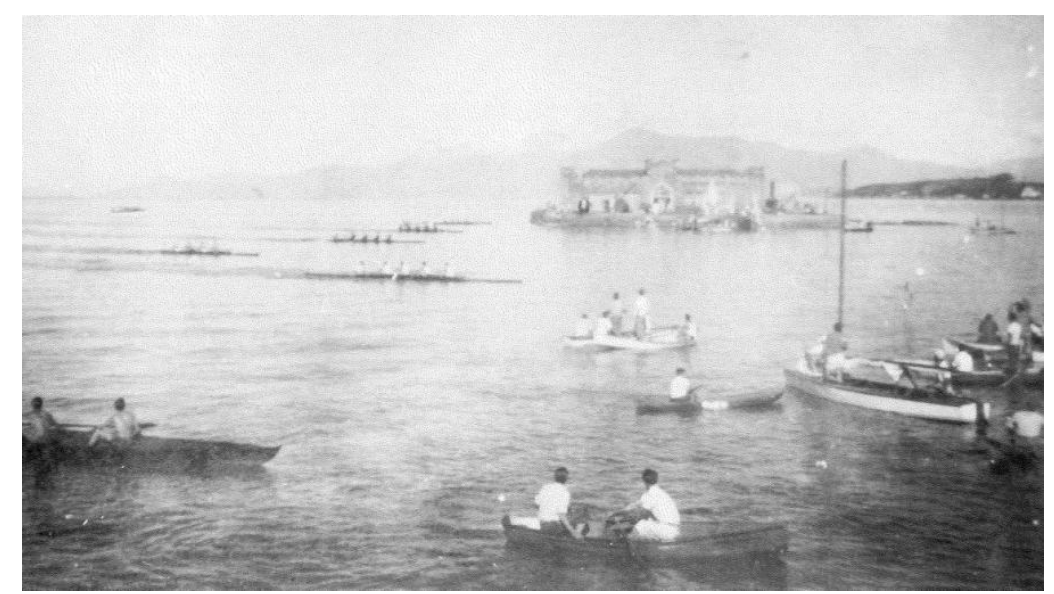

Imagem No 13: Regatas em torno da Ilha do Carvão.

(Acervo do Clube Náutico Riachuelo)

Até meados da década de 1970, era possível ver, na baía Sul, a Ilha do Carvão. Hoje, subsiste sua vaga lembrança entre os remadores mais velhos. Ela abastecia de carvão os navios a vapor que usavam o porto da cidade e fazia parte da paisagem local, compondo uma linha reta que começava no cais Rita Maria, usada nas competições. O que restou está nos arquivos e acervos públicos ou particulares em forma de fotografias, audiovisuais e reportagens de jornal. E ainda no imaginário daqueles que apenas ouviram relatos sobre ela. Com a chegada do aterro, a baía se converteu na base de apoio para a construção da ponte Colombo Salles, que hoje conecta a ilha ao continente. $\mathrm{Na}$ Imagem $\mathbf{N}^{\mathbf{0}} \mathbf{1 4}$, podemos ver como os pilares da ponte Colombo Salles são sustentadas na base onde se localizava essa ilha, mas a imagem dos remadores ao redor dela ainda permanece, apesar de todas as transformações.

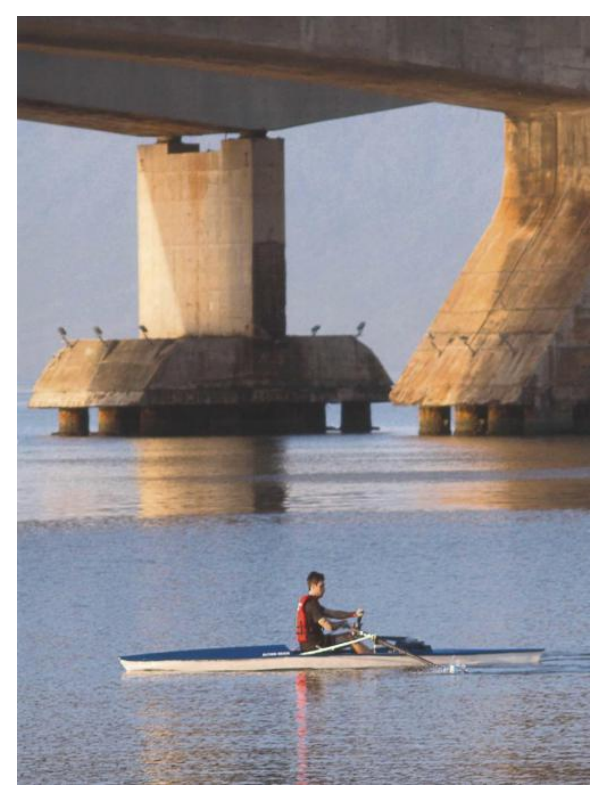

Imagem $N^{0}$ 14: Pilares da Ponte Colombo Salles. (Acervo do Clube Náutico Riachuelo) 
Depois da experiência que o Clube 29 de Abril deixou na cidade, quase dez anos mais tarde, o incentivo que faltava para a consolidação do remo, como projeto universalizador, partiu do apoio do governo local e de comerciantes da área central. No dia 11 de junho de 1915, foi fundado o Clube Náutico Riachuelo. O nome trazia uma homenagem à Batalha Naval do Riachuelo e foi representado com as cores azul e branco em seu brasão. Ele nasceu carregando em seu lema na "grandeza da sua história, fulgura a força", como uma referência às conquistas da Guerra do Paraguai. Hoje, é possível apreciar uma réplica da imagem dessa batalha na parte superior da porta que dá acesso à sala da diretoria do clube - o espaço administrativo onde se tomam decisões -, como vemos na Imagem $\mathbf{N}^{\mathbf{0}} \mathbf{1 5}$, trazendo uma representação iconográfica em tamanho grande, que nos remete ao quadro Combate Naval do Riachuelo, de Victor Meirelles (1832-1903) ${ }^{18}$.

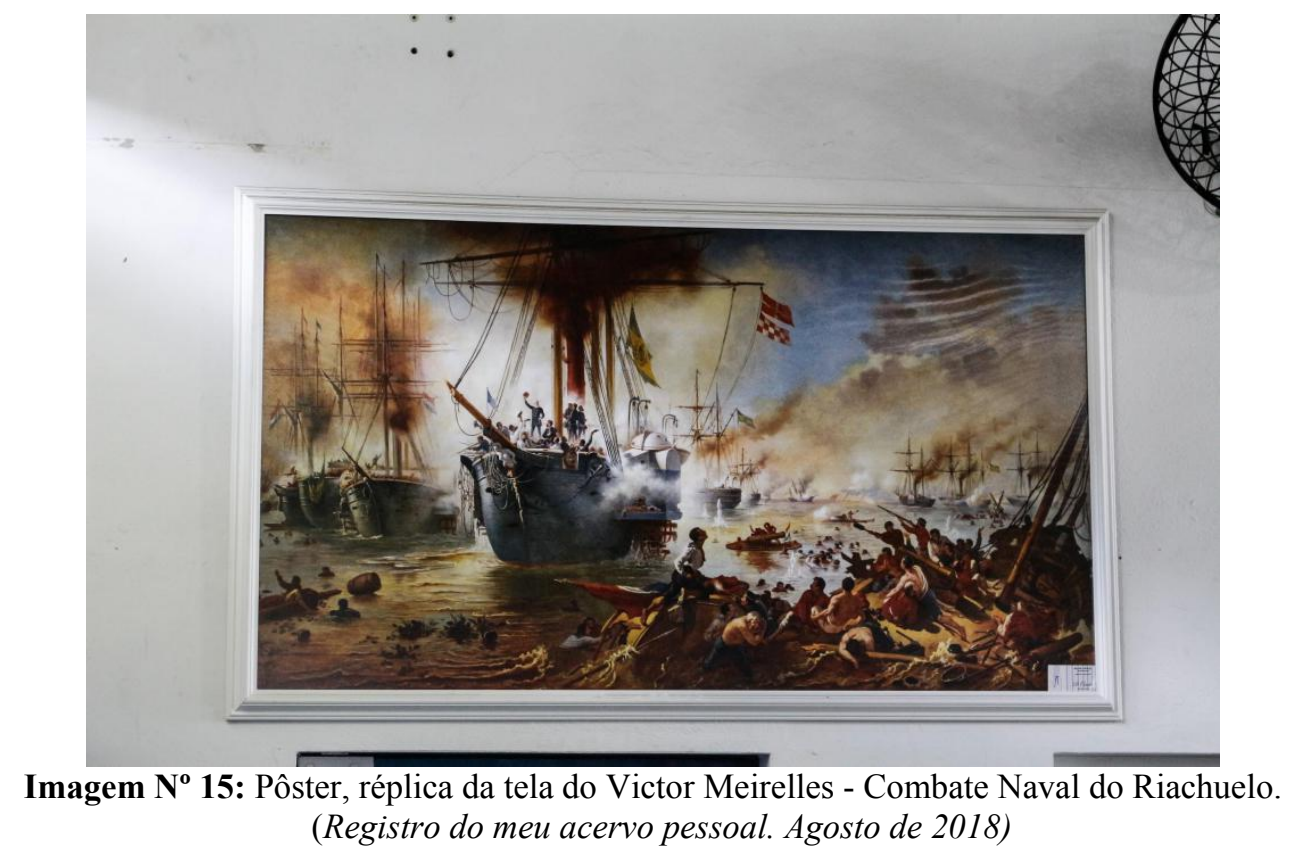

A obra de Victor Meirelles é carregada de significados político e simbólico não só para os riachuelinos. A imagem é considerada por muitos historiadores como um expoente desse período de transição entre o Império e a República. O pintor da obra, que nasceu em 18 de agosto de 1832, na antiga vila de Nossa Senhora do Desterro,

\footnotetext{
${ }^{18}$ A pintura original foi feita em óleo sobre tela, cujas dimensões são de 8,2 metros de largura por 4,2 metros de altura. A obra foi encomendada pelo Ministro da Marinha, Afonso Celso de Assis Figueiredo, em 1868, e retrata um confronto naval que aconteceu na Guerra do Paraguai entre a esquadra brasileira e a paraguaia em um trecho do Rio Prata.
} 
numa casa de esquina na Rua Saldanha Marinho, filho de uma família de comerciantes, era considerado pela elite florianopolitana como um artista prodígio e tido como um homem metódico, sem vício e modesto. Valores que coincidem com o ideal branqueador que orientava a moral da elite local. Dedicou grande parte da sua pintura às cenas históricas e às batalhas nacionais, tornando-se um dos pintores preferidos de $\mathrm{D}$. Pedro II, que o inseriu no programa de mecenato, alinhando-o à sua proposta de renovação da imagem do Brasil por meio da criação de símbolos visuais.

A Guerra do Paraguai, como é chamada no Brasil, através de seu nome faz uma referência a quem carrega a culpado do conflito, o Paraguai. Com esse nome, o Brasil parece se eximir da sua responsabilidade perante às demais nações. Na Argentina e no Uruguai, por exemplo, o nome varia no imaginário e na historiografia dos países vizinhos, sendo conhecida como a Guerra da Tríplice Aliança. Esse nome faz uma clara referência ao conluio ou à aliança entre Brasil, Argentina e Uruguai, contra o Paraguai. Já no Paraguai, o evento é conhecido como La Guerra Grande, justamente porque foi a guerra que acabou destruindo de fato o país, dizimando quase a totalidade da sua população masculina. Ela é considerada até hoje o maior conflito armado da América do Sul e, como toda guerra, como todo conflito, ela criou suas próprias narrativas, as suas próprias verdades nas diferentes nações que participaram.

Uma dessas verdades é que o Brasil dos finais do século XIX, ainda nas mãos do Império de Dom Pedro II, vivia o seu maior apogeu econômico, especialmente com o advento da produção de café, que foi conhecido como o "ouro preto" daquela época. No início da guerra, até era considerado prestigioso participar das batalhas, como um valor que estaria atrelado a uma questão da honra dos homens que iam ao combate. Mas, no fim da guerra, o Brasil terminaria sucumbido a uma decadência econômica por conta dos gastos bélicos e hospitalares. A guerra acabou se convertendo num evento em que ambas as partes acharam que seria muito curto, mas acabou se estendendo por seis longos anos e arrasou com a economia de todos os países envolvidos. Esse momento de pós-guerra, e crise econômica, coincidiria com a tomada de forças do partido republicano, do abolicionismo e dos grandes grupos opositores a Dom Pedro II.

Mesmo com o final trágico, o governo imperial fez um investimento enorme para criar suas próprias narrativas e verdades sobre a guerra, a partir do financiamento de artistas como Victor Meirelles e Pedro Américo de Figueiredo e Melo (1877), visando eternizar aqueles momentos, como a Batalha do Riachuelo e a Batalha do Avaí, citando alguns, como forma de exaltação cívica, para que a população contemporânea e 
a posteridade se identificassem com um episódio memorável da História do Brasil através da atuação da Marinha. Essas diferentes narrativas históricas sobre a Guerra, construídas durante esse período e, especialmente as narrativas visuais construídas na pintura, levam-nos diretamente a pensar nesse embate entre memória e história.

O remo catarinense, que surge com potência e protagonismo social no início do século XX, quase 40 anos depois dos acontecimentos bélicos, retoma toda essa simbologia das grandes batalhas navais, produzidas nessas narrativas do fim de um segundo reinado, num período de transição republicana e de uma forma menos preocupada com os dados oficiais sobre as perdas que a guerra gerou para o Império. Recria sua própria narrativa, positiva, sobre elas, de forma mais subjetiva, como diria Lilia Schwarcz (2005), sobre as ideias de "brilho" e "força", como menciona a estrofe do hino, reconstruindo um discurso de nacionalidade que, até os dias de hoje, continua sendo um elemento fundamental para a identidade dos riachuelinos.

\section{A emergência da cidade}

Há poucos meses da fundação do Clube Náutico Riachuelo, um grupo de comerciantes do centro da cidade se reuniu com o intuito de fundar outro clube de remo. No dia 31 de julho de 1915, foi fundado, então, o Clube Náutico Francisco Martinelli. O nome foi dado em homenagem ao jovem guarda-marinha Francisco Martinelli que, segundo a Revista Ilustrada ${ }^{19}$, de 20 Março de 1920, "triunfará em toda a sua carreira: que subira os degraus por esforços próprios, maravilhando seus amigos, enternecendo seus mestres, enchendo de lágrimas doces os olhos da dolorosa velhinha Martinelli”.

Com a chegada do novo clube - que tinha as cores vermelho e preto como homenagem a um naufrágio de uma viagem da escola naval em 1913 -, ampliaram-se as opções para as competições das regatas, pois o Martinelli se caracterizava pela sua posição não elitizada de seus participantes e associados. Sua proximidade com a vida comercial do centro rendeu-lhe o título de "o clube mais querido" da cidade, deixando para os torcedores do Riachuelo a região da Rita Maria, na Beira Mar Norte, para que se aglomerassem. As festas de comemoração e os eventos competitivos mais nobres de ambos os clubes ficavam restritas apenas aos associados, conforme a classe social e o

${ }^{19}$ FILHO, Barreiros. Revista Ilustrada, 20 Março de 1920. Cd. SARTORI, Carina. Na alvorada de um sport: o remo na ilha de Santa Catarina. 2003. Dissertação Mestrado, Universidade Federal de Santa Catarina, Centro de Filosofia e Ciências Humanas - Programa de pós-graduação em História. 
evento em questão. Esses eventos serviram, também, como palanque político, ao construir uma imagem para as torcidas vinculada ao clube em evidência ${ }^{20}$.

As regatas costumavam acontecer em frente ao Mercado Público, no antigo Miramar, como aparece na Imagem $\mathbf{N}^{\mathbf{0}} \mathbf{1 6}$, e chegavam a reunir um público de seis mil torcedores aproximadamente. No início do século XX, Florianópolis contava com cerca de 15 mil habitantes e, em 1940, sua população passou a 25 mil habitantes, pois naquela década a Ilha agregou uma parte do continente que pertencia a São José. Até então, a capital catarinense era considerada apenas uma região da Ilha (Sartori, 2003: 84), e as torcidas se acumulavam nos trapiches, bem perto de onde partiam os barcos.

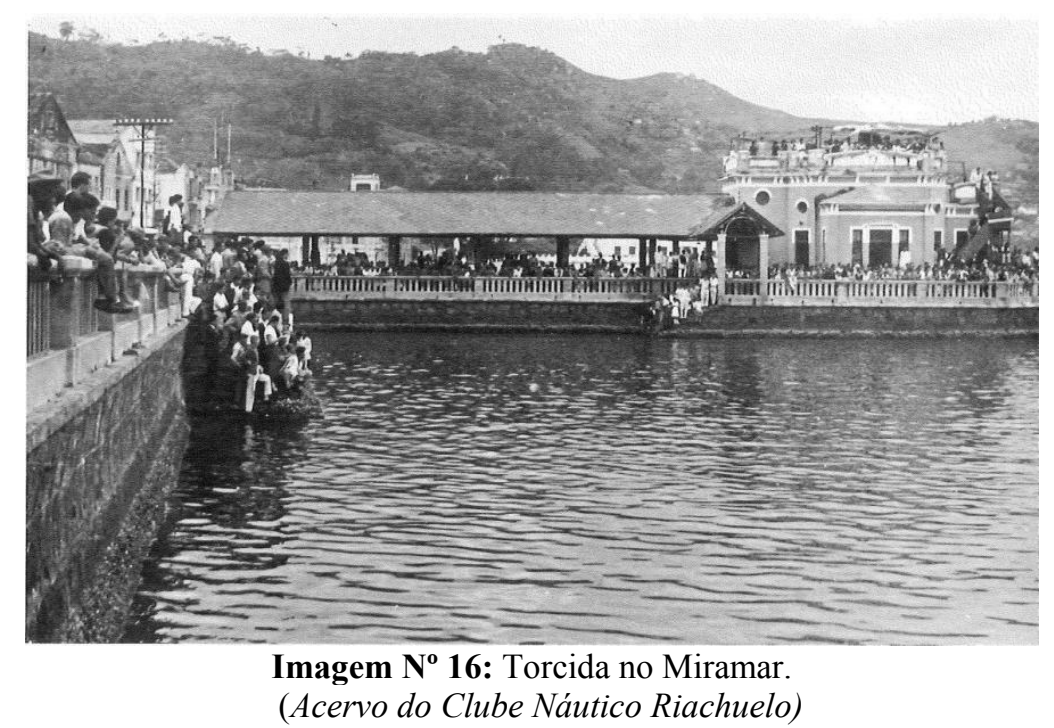

Se, por um lado, a prática do esporte cabia à alta sociedade catarinense, cabia aos menos privilegiados o incentivo por meio da participação na torcida, às margens próximas às competições, como vemos na fotografia acima. O Riachuelo estava ligado às famílias Muller, Mund, Moritz e Hoepcke, todas de origem alemã e detentoras da maior parte do comércio da ilha. O Francisco Martinelli era integrado por comerciários menores e um terceiro clube, o Aldo Luz, que surgiria em 1918, e seria comandado eternamente por Aderbal Ramos da Silva, governador, deputado e mandante perpétuo da política catarinense, até seu falecimento (Ferreira, 1998: 59) ${ }^{21}$. Dando sequência à

\footnotetext{
${ }^{20}$ Para mais dados sobre a formação das torcidas de remo nesse período e seu papel na sociedade, ver os trabalhos de: SILVEIRA, Arthur Fernandes. História do Remo em Florianópolis, 1950 - 1970. Trabalho de Conclusão de Curso da Universidade Federal de Santa Catarina. 2008. BORGES, M.D.G. Remando nas Águas da História: As heróicas conquistas do Remo de Santa Catarina 1861- 2002. Florianópolis: Imprensa Oficial do Estado De santa Catarina, 2002.

${ }^{21}$ FERREIRA, Sérgio Luiz. O banho de mar na ilha de Santa Catarina. Florianópolis: Ed. Das Águas, 1998: 59.
} 
fundação dos três clubes, inaugura-se a Federação Catarinense de Desportos Aquáticos, em 1919, que recebeu o mérito de organizar a prática do remo e de elevar o número de competidores e das competições ${ }^{22}$.

A política implantada junto com o surgimento da Federação apontava para a modificação dos costumes locais, considerados provincianos e atrasados aos novos padrões de sociedade republicana e urbana, inspirados na capital Rio de Janeiro. Visava também uma modernização física da cidade, em infraestrutura, para fortalecer sua formação como capital do Estado de Santa Catarina (Imagens 17, 18, 19. 20, 21, 22, 23). Novos costumes significavam a construção de uma elite local que se firmasse por meio da participação nos clubes de remo e, ao mesmo tempo, que aderissem ao projeto da modernidade por meio deles. Isso causou uma segregação entre as pessoas: de um lado, os pescadores e trabalhadores braçais e, de outro, aqueles que tinham uma influência política, intelectual ou financeira maior sobre a parte restante, como os altos comerciantes e políticos. As participações nos campeonatos estavam diretamente ligadas ao status social da elite local que, para isso, não poupou esforços na marginalização da população que não se enquadrava na nova política florianopolitana de modernização. As regatas na orla tornavam-se, nessas ocasiões, espaços de encontro.

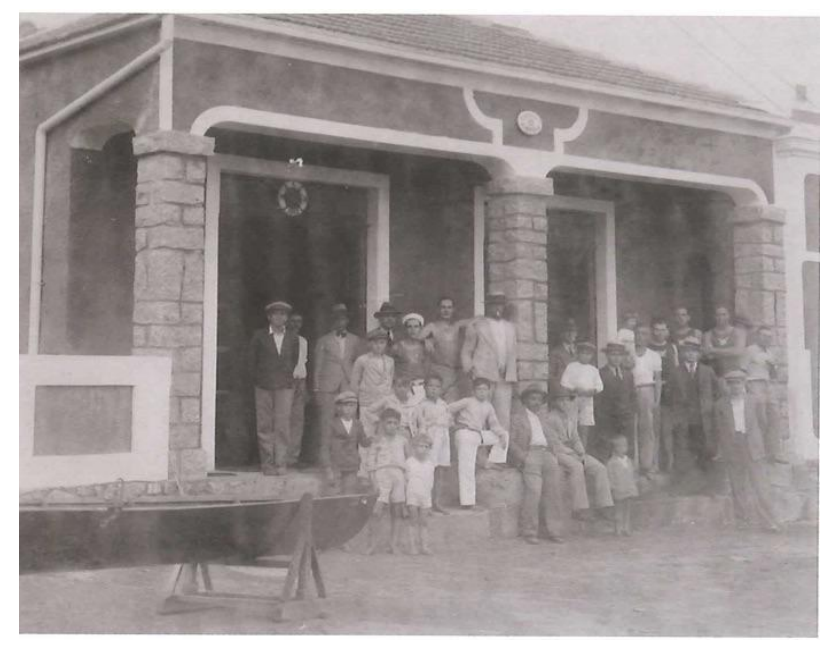

\author{
Imagem $\mathbf{N}^{\circ}$ 17: Torcedores \\ e dirigentes do Riachuelo. \\ (Acervo do Clube Náutico Riachuelo)
}

As primeiras décadas do século XX trouxeram a abertura e o calçamento de ruas, a ordenação e limpeza das praças, bem como a realização de obras que garantissem a manutenção da nova ordem e do novo modo de vida. O transporte

\footnotetext{
${ }^{22}$ Vários historiadores coincidem com que a chegada dos três clubes, e, especialmente a data da fundação do Aldo Luz e a data de fundação da Federação Catarinense de Desportos Aquáticos
} 
marítimo que levava homens, mulheres e crianças da Ilha ao continente, ou vice-versa, sofreu alterações. O mar, que já havia sido um dos principais lugares de serviço para os moradores de Desterro durante parte do século XIX - pesca, extração, despejo e meio de comunicação -, sofreria, então, sua primeira intervenção, com um traçado de orla por amontoados de pedras que constituíam pequenas praias na parte Norte da Baía e ao Sul, um amontoado de trapiches, para abrigar os espaços de disputas do remo.

Até o ano de 1926, a única conexão entre a ilha e a porção continental era por via marítima através da travessia ilha, continente. Nesse período, a principal atividade econômica era a pesca. No entanto, todas as atividades econômicas necessitavam do uso de barcos para transitar entre a ilha e o continente. Em 1926, foi construída a Ponte Hercílio Luz, com 831 metros de extensão (a primeira ponte entre o continente e a ilha). Esse fato trouxe uma grande expansão do comércio. O modo de transporte terrestre via caminhões e carros passou a representar o principal meio de circulação a partir dessa época. Com essas melhorias no sistema de transportes, aumentou o fluxo diário de pessoas e bens, assim como a expansão das atividades mercantis. O traçado urbano sofreu modificações para que ocorresse a nova ligação entre a ilha e o continente, como a instalação das primeiras redes de água, esgoto, energia elétrica, pavimentação, alinhamento de ruas e mudança do cemitério.

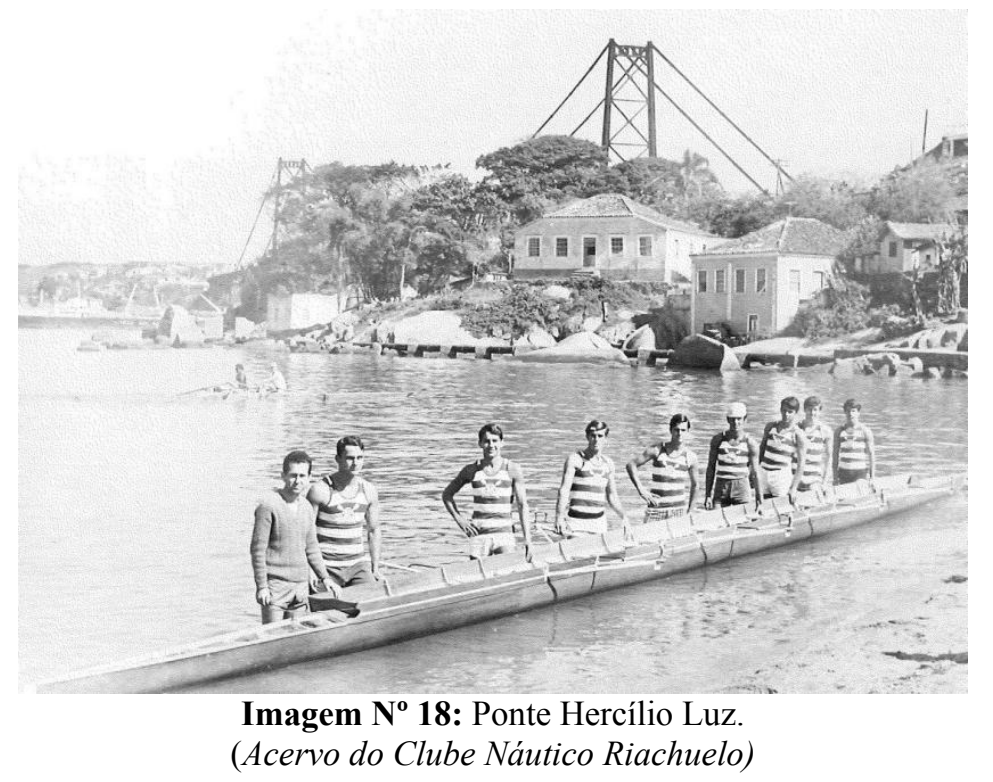

A Avenida Hercílio Luz teve o Rio da Bulha canalizado para receber a pavimentação e ajardinamento após as demolições dos cortiços. As ruas foram calçadas e devidamente nomeadas em homenagem a personalidades republicanas. A construção 
do Miramar, no final da década de 1920, em substituição ao velho Trapiche Municipal, foi um projeto que se inseriu nas perspectivas modernizadoras da capital.

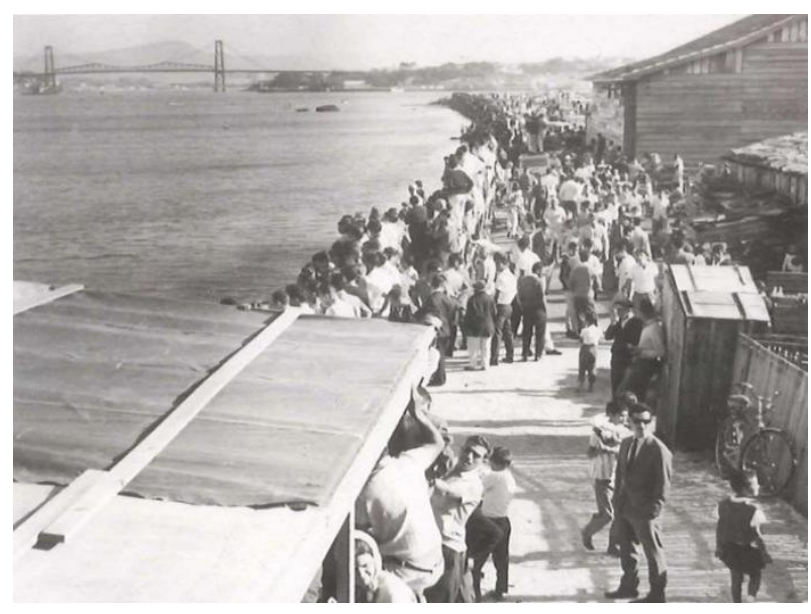

Imagem $\mathbf{N}^{0}$ 20: Superior. Torcedores carregando barco ganhador. Praia do Rita Maria. (Acervo do Clube Náutico Riachuelo).
Imagem No 19: Regatas na Prainha. (Acervo do Clube Náutico Riachuelo)
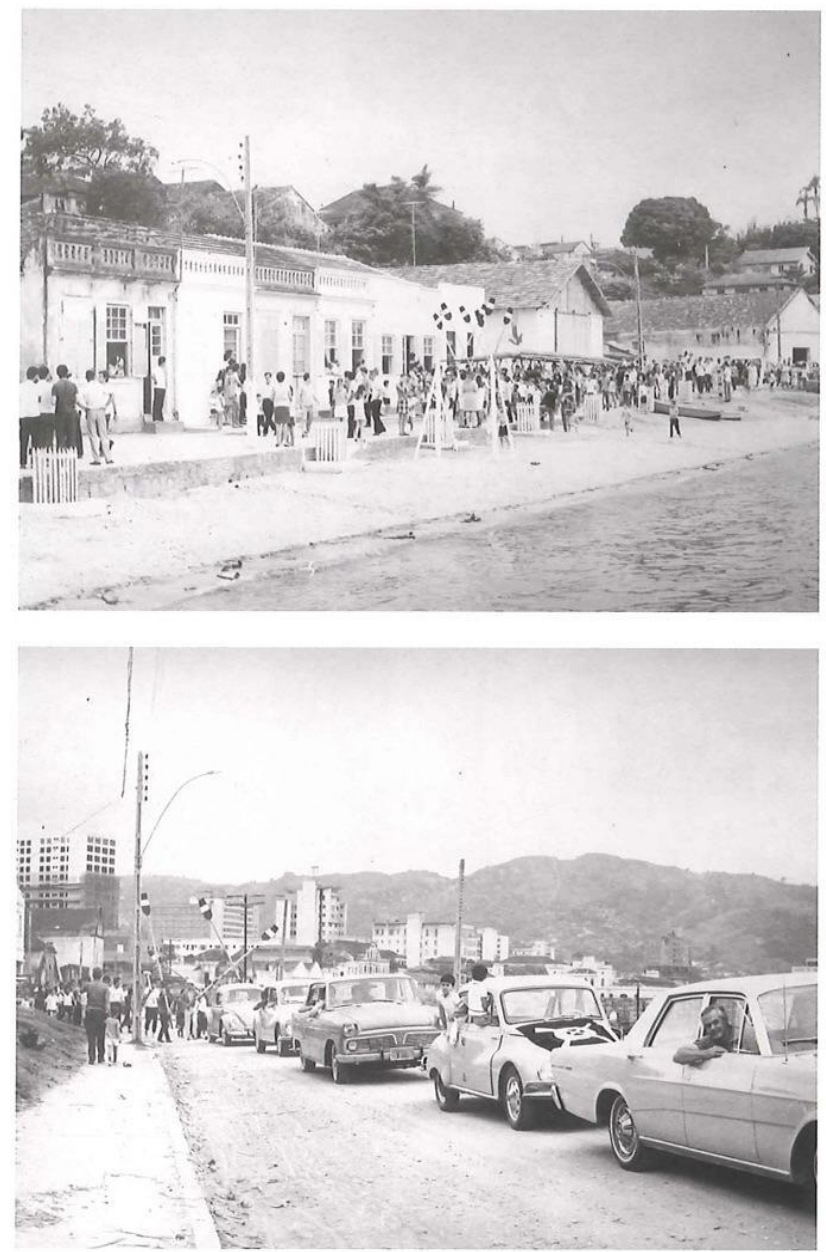

Imagem $\mathbf{N}^{\mathbf{0}}$ 21: Carreata pela cidade comemorando vitória do Riachuelo. (Acervo do Clube Náutico Riachuelo). 

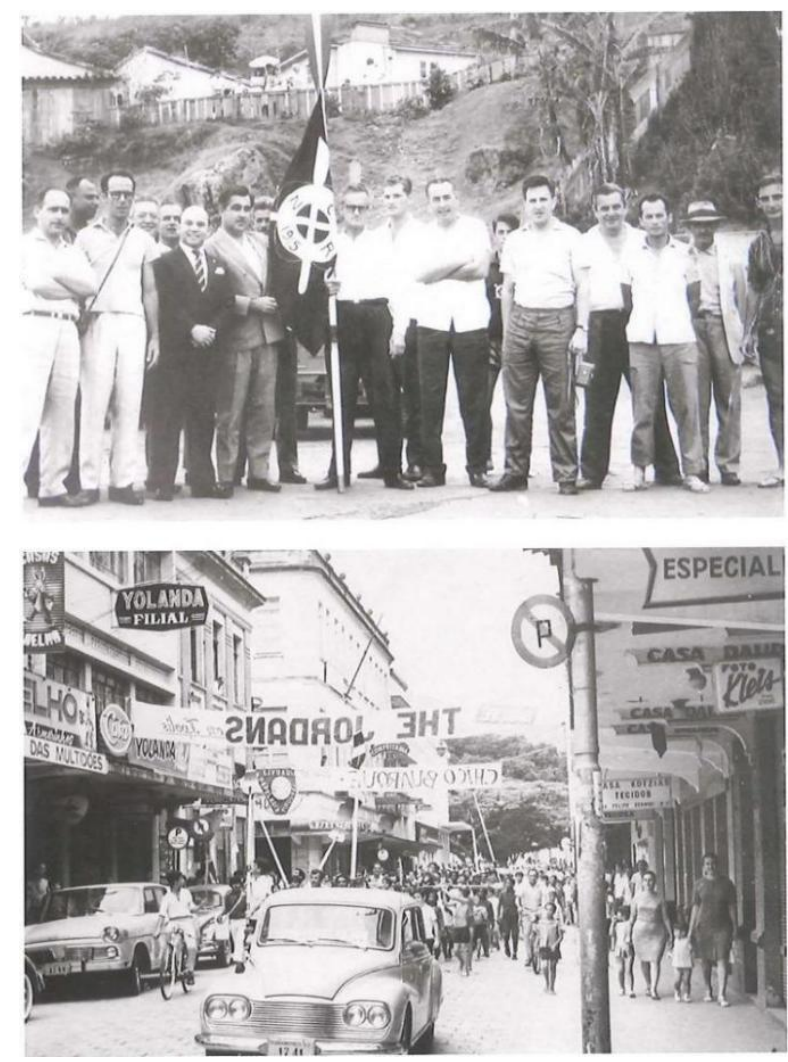

Imagem No 22: Diretores do Clube Náutico Riachuelo.

(Acervo do Clube Náutico Riachuelo).

\author{
Imagem $\mathbf{N}^{\mathbf{0}}$ 23: $\mathrm{O}$ barco ganhador sendo \\ carregado pelos torcedores pelo centro de \\ Florianópolis. \\ (Acervo do Clube Náutico Riachuelo)
}

\section{Avançou a cidade, contraiu o mar}

Os chamados "tempos de glória" do remo, em Florianópolis, tiveram seu auge entre os anos 1920 e 1940. Mesmo com a adesão massiva das pessoas às torcidas de futebol desde meados dos anos 30, o remo ainda assim conseguiu se manter numa certa vida ativa dentro da cidade e, até a década de 1960, conseguiu manter um certo protagonismo social e visibilidade. A maioria dos remadores mais velhos, com quem convivemos em campo, os companheiros de Seu Décio, começaram e viveram grande parte da sua carreira dentro da água nessa década, e todos eles passaram pelo que eles mesmos chamam de "início da decadência do remo", com a chegada dos aterros. Lauro, que é responsável pela educação técnica dos novos atletas, foi um remador reconhecido e teve uma vida inteira ligada ao clube Riachuelo. Ele descreve esse processo como " $O$ aterro quase acabou com o remo", e acrescenta: 
A mudança foi quase que inadmissível naquele tempo, especialmente pela rivalidade entre os clubes, mas junto com a chegada do aterro foi minguando a popularidade do remo. $\mathrm{O}$ aterro acabou tudo. Os clubes ficaram longe das raias. Quase morreu o remo. Sobreviveu com muito esforço de quem gosta!

No fim da década 1960, um projeto de crescimento urbano se instalou em Florianópolis, com o objetivo de expandir o zoneamento urbano e promover a circulação de bens e pessoas, com a promessa que trariam benefícios através de atividades econômicas e da apropriação e uso de espaços construídos. Assim, surge o aterro da baía sul. Na época, a construção do aterro foi considerada fundamental para o desenvolvimento urbano e status quo do município de Florianópolis, que, segundo Cunha $(2005)^{23}$, cresceu intensivamente depois de criar uma área triangular de desenvolvimento com vértices apoiados na ponte na direção oeste, ao sul, e ao norte. Soterrando assim a região da Rita Maria até a Região da Prainha, retirando as sedes das agremiações de remo do centro da cidade e colocando-as na nova região do aterro da baía sul, chamada de Parque Náutico Walter Lange, embaixo das Pontes Colombo Salles e Pedro Ivo, como vemos na Imagem No 24.

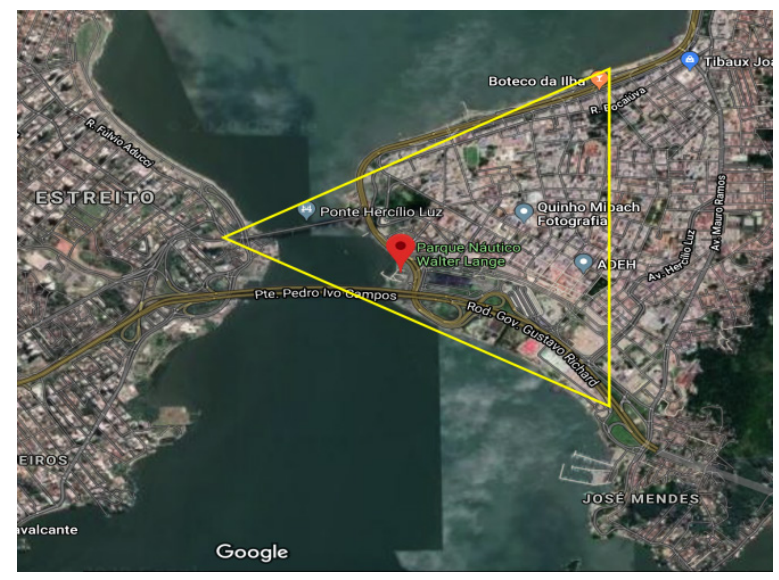

Imagem No 24: Parque Náutico Walter Lange. (Print do Google Maps, Acessado em Novembro de 2019)

O aterro acabou moldando a formação urbana de Florianópolis e, a partir do ano de 1972, novas áreas comerciais, portuárias, industriais e residenciais emergiram em diferentes lugares dentro ou no seu entorno. O aterro modelou a expansão da linha de costa e, com isso, o desenvolvimento de atividades comerciais ligadas às atividades

\footnotetext{
${ }^{23}$ CUNHA,G.S.: Considerações sobre o aterro de Florianópolis, 2005. 10 f. Trabalho de conclusão de Curso (graduação) - Universidade Federal de Santa Catarina.
} 
portuárias. A implantação se deu no governo de Colombo Salles (1972-75), seguida da construção da Ponte Colombo Salles inaugurada em 1975, que acabou soterrando a Ilha do Carvão. Fábio Bruggemann tenta lembrar a Ilha do Carvão, buscando no esquecimento: "Dizem que foi pisada pelo pilar da ponte Colombo Salles. Outros dizem que ela se enterrou no centro do lago das bandeiras, no vazio defronte ao Terminal Rita Maria. Entrou, aos poucos, na área sombrosa da amnésia. Sofreu terras. Contraiu cidade".

Essa segunda ponte permitiu uma ampla integração com as demais capitais brasileiras, em especial as capitais dos Estados do Sul do país. No ano de 1978, a fachada do Mercado Público deixou de ser banhada pelas águas do oceano e o aumento das fronteiras da cidade sobre as águas fez com que outras coisas aumentassem, como o sistema viário, as áreas para prédios públicos, residências, indústrias, estabelecimentos comerciais e construção de áreas de recreação e esportes. Avançou a cidade, mas o mar contraiu, na perspectiva do remadores.

Os clubes de remo foram retirados do centro e realocados, "jogados fora", nas palavras de Lauro. Os novos galpões eram padronizados, doados pela prefeitura, conforme mostra a Imagem $\mathbf{N}^{\mathbf{0}} \mathbf{2 5}$. Com o aterro da Baía Sul, os tempos áureos do remo de Florianópolis ficaram enterrados na memória dos remadores da geração de Lauro e Seu Décio. As fotografias do acervo do Clube Náutico Riachuelo, que ilustram os trapiches cheios de gente para assistir às regatas, as torcidas organizadas para cada clube aglomeradas nas ruas próximas ao Mercado Público, as ruas do centro invadidas pela festa dos vencedores, tudo isso ficou na lembrança daqueles que hoje evocam a recordação.

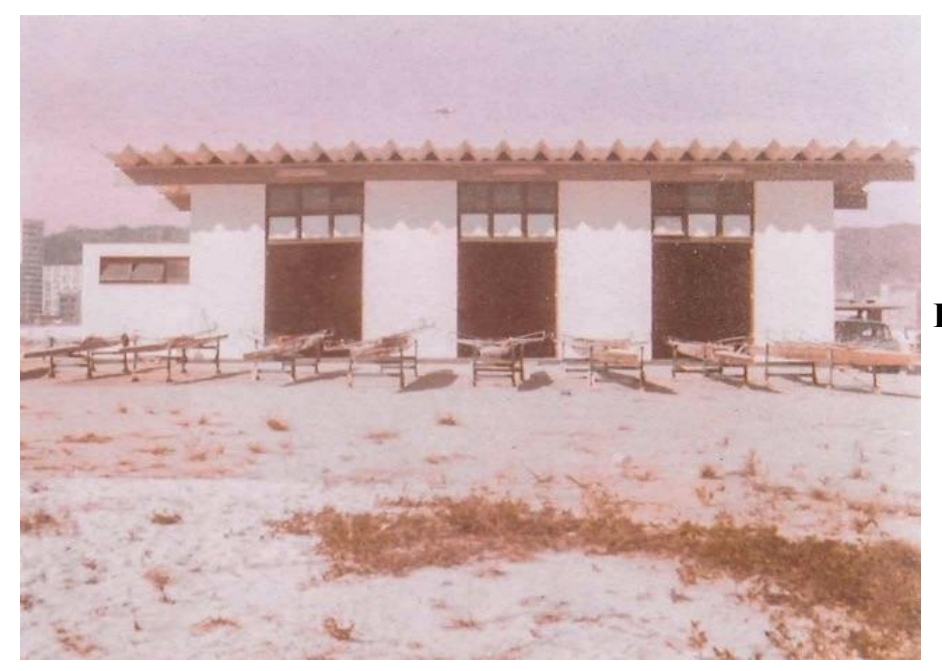

Imagem N²5: Novo Galpão do Clube Náutico Riachuelo. (Acervo do Clube Náutico Riachuelo) 
Hoje, é possível observar como as grandes infraestruturas que rodeiam o Parque Náutico engoliram e isolaram os clubes, dificultando seu acesso, ficando quase ocultos da paisagem urbana, destinando-os ao limiar do esquecimento, como fica visível nas Imagens 26 e 27.

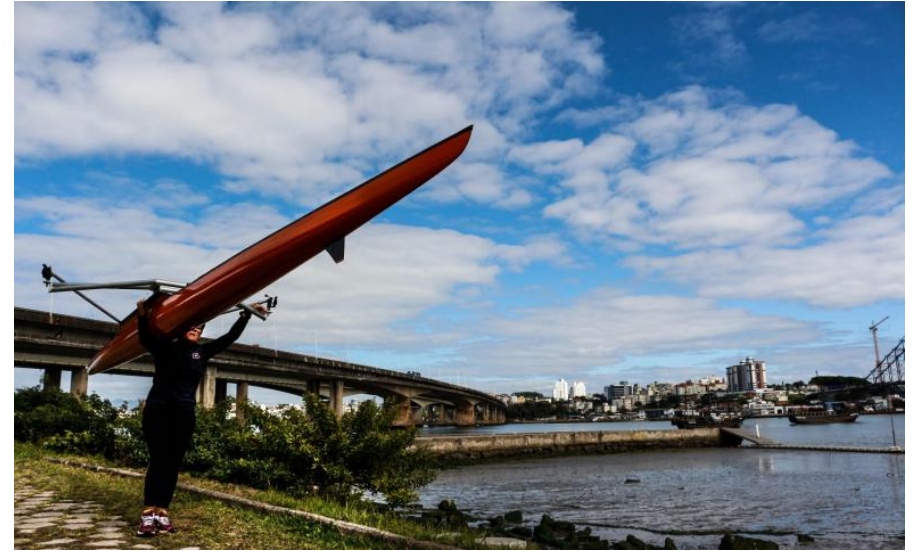

Imagem $\mathbf{N}^{0}$ 26: Ponte Colombo Salles. (Registro do meu acervo pessoal. Agosto de 2018.).

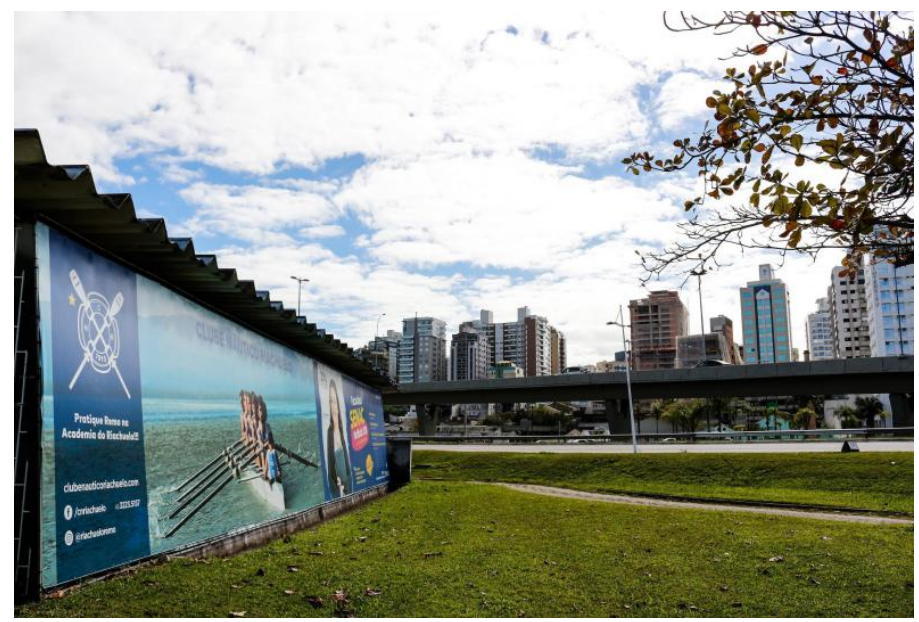

Imagem $N^{0}$ 27: Viaduto Região Rita Maria (Registro do meu acervo pessoal. Agosto de 2018)

Essas imagens fazem parte do nosso acervo porque no acervo deles essa parte da memória foi "esquecida", ou seja, não encontramos imagens que façam referência às novas configurações do espaço ou mesmo ao processo de afastamento do centro para as periferias. A distância entre os galpões hoje é muito maior do que aqueles poucos metros que os 
separavam, é uma distância simbólica que se mede pelo status e pela rivalidade centenária entre eles. Manter essa distância e rivalidade faz parte do ethos ${ }^{24}$ dos remadores riachuelinos, dos aldistas e dos martinelistas. Na Imagem $\mathbf{N}^{\mathbf{0}} \mathbf{2 8}$, aparecem os três galpões, um ao lado do outro. O primeiro, com a fachada azul, é o Riachuelo. Logo ao lado, o galpão do Aldo Luz, com detalhes em vermelho nas portas, e, por último, quase chegando a ficar embaixo da ponte, aparece o galpão do Francisco Martinelli.

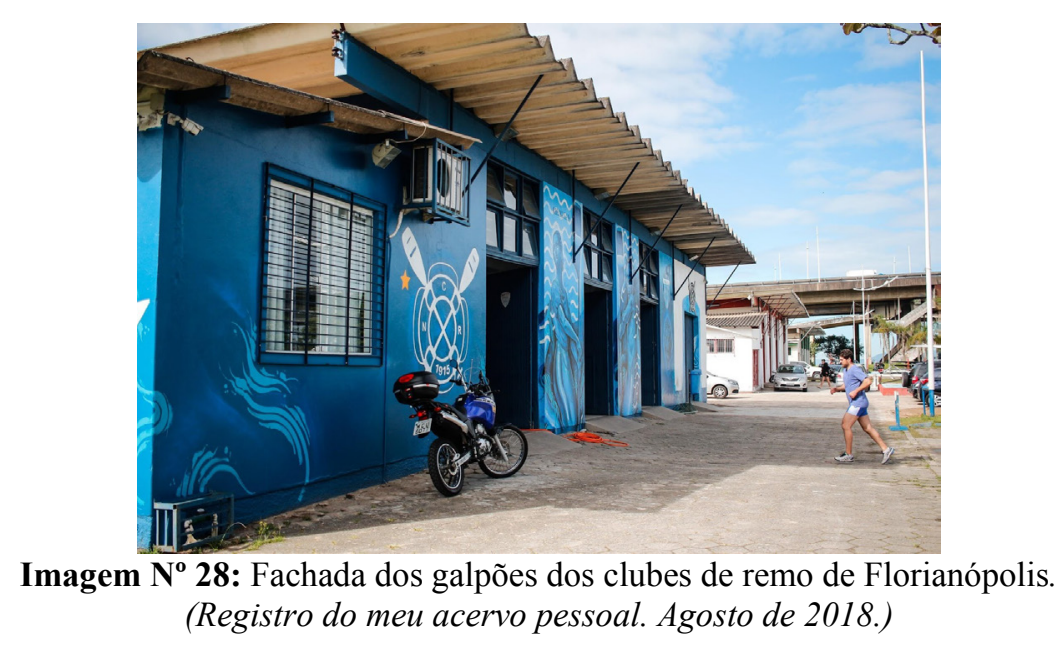

Em março de 2016, um acontecimento marcante trouxe à tona a situação de abandono que os riachuelinos reclamam em relação ao espaço que lhes foi destinado: a triste notícia de um assassinato ocorrido à noite, nos arredores dos galpões dos clubes. A vítima foi assassinada por um morador de rua e, segundo a polícia que conversou com os frequentadores dos clubes, eles têm uma visão comum sobre o espaço, alegando que:

O lugar está tomado por usuários de drogas. O local é usado por esportistas durante o dia, e a noite se transforma em ponto de encontro para uso de entorpecentes. Afirmam que este problema inclusive tem feito pais desistirem de matricular os filhos mais novos no curso. Aqui a gente tem uma cultura saudável, de esportes. Ensinamos valores para os alunos. E aí eles saem para o parque e se deparam com usuários de drogas.

Esse depoimento foi retirado de uma reportagem feita por um jornal local ${ }^{25}$, com o título de "Medo afasta frequentadores e moradores de rua do parque náutico, no centro de

24 O conceito de ethos, desenvolvido na antropologia por Bateson (2008), faz referência aos aspectos da formação afetiva dos indivíduos, que são enfatizados em contextos de grupos e, em graus variados, dependendo do contexto, criam diferenças profundas na personalidade dos sujeitos (Bateson, 2008, pág. 285-286).

${ }^{25}$ NSC Total publicado em 14/03/2016. 
Florianópolis": Local é frequentado por usuários de drogas durante as noites.

\section{Uma memória em duas direções}

"Fotografia é o espelho que lembra", diz a frase homônima citada por Walter Benjamin $(2006)^{26}$, numa página do livro "Passagens". Ele nos remete ao outro mundo do que foi, mas não é mais, e continua sendo. Benjamin faz o exercício da memória a partir de relatos fragmentados, inacabados, de uma Paris que já não existe.

A capital do século XIX foi uma espécie de protótipo das grandes cidades fora da Europa, com atenção e ênfase às galerias comerciais como primeiras paisagens do consumo. A capital francesa apresentou e representou a história da cotidianidade moderna, e Benjamin faz uma provocação nesse livro, convidando-nos a pensar a vida nas cidades a partir dessa Paris que descreve. Com isso, ele nos ajuda a pensar nos problemas que a cada dia ganham novas configurações sociais, políticas e econômicas. Cabe dizer que a alegoria que Benjamin apresenta de Paris é uma alegoria do próprio projeto da modernidade, dando-nos a possibilidade de revelar as iniquidades que se encontram detrás dessa falsa totalidade harmoniosa e organizada. A frase "ordem e progresso", como foi traduzida no Brasil da Primeira República, veio carregada de novas infraestruturas urbanas e, em Florianópolis, essas infraestruturas deram formas materiais a transformações que possibilitaram a troca no espaço e nas redes físicas através das quais começaram a traficar bens, ideias, desperdício, poder, pessoas e finanças (Larkin, 2013) ${ }^{27}$.

Quando chegou a Florianópolis, esse projeto foi implementado com a ajuda do remo como prática esportiva entre as camadas sociais elitizadas que, em grande parte, pactuaram com essas premissas, na sua tentativa de se diferenciarem do mundo da pesca. Fazia sentido ter clubes de remo na Inglaterra, em Paris ou no Rio de Janeiro, fazia sentido aqui também. Florianópolis é a sua forma, é também resultado de processos coloniais ainda em curso, que visam pensar modernidade como um sistema abstrato, universal, independente da condição histórica de onde está. Quando olhamos o acervo fotográfico do Clube Náutico Riachuelo, seja qual for a avaliação ou juízo que fizermos das imagens que analisamos, elas sugerem uma percepção de Florianópolis, a partir dos fragmentos imagéticos como partes de uma

\footnotetext{
${ }^{26}$ BENJAMIN, Walter. Passagens de Walter Benjamin. TIEDEMANN, Rolf; BOLLE, Willi; MATOS, Olgária Chaim Feres (Org.). Trad. Irene Aron e Cleonice P. B. Mourão. Belo Horizonte: UFMG/Imprensa Oficial de São Paulo, 2006.

${ }^{27}$ LARKIN, Brian. The Politics and Poetics of Infrastructure. Barnard College, Columbia University, New York, NY 10027-6598; email: bl190@columbia.edu
} 
história inacabada ou de uma memória que se reinventa constantemente.

Essa memória é marcada por imagens que refletem as transformações da infraestrutura da cidade. As pontes, os aterros, as ruas e as construções que constituem as imagens são formas, as quais, "não simplesmente exprimem transformações históricas mas agem nas pessoas para produzir novas experiências do mundo" (Larkin, 2015) ${ }^{28}$. E aqui a história é escrita a partir do contato sensorial com as fotografias, que são lembradas ou esquecidas para se posicionar de frente para a oficialidade histórica que lhes são outorgadas. Uma oficialidade entrelaçada com um projeto modernizador, que fundamenta a prática do remo e as formas estéticas das imagens aqui propostas, mas que nega também essa prática, dependendo da agressividade das transformações infraestruturais da cidade.

Esse exercício realizado pelos riachuelinos, por motivo da comemoração do centenário do clube, de reunir imagens, olhar para elas e recordar, pode nos ensinar como uma pesquisa sobre as cidades pode nos conduzir a uma reflexão maior em torno das fissuras e dos interstícios da sociedade florianopolitana contemporânea. A memória dos remadores funciona com o princípio de montagem, onde, justapondo-se fragmentos imagéticos do passado e do presente, possibilitam, faiscando entre si, iluminar uns aos outros lugares, como a região do Rita Maria, ou da extinta Ilha do Carvão e, a partir disso, entender, quem sabe melhor, a cidade em que vivemos hoje.

A memória da cidade de Florianópolis, contada pelos riachuelinos, assemelha-se ao movimento dos braços para completar a remada, um esforço para frente e outro para trás. Como nos lembra Benjamin, a memória é essencialmente entradas e saídas ao mesmo tempo.

A nova forma da ponte Hercílio Luz ao fundo, na Imagem $\mathbf{N}^{\mathbf{0}} \mathbf{2 9}$, é feita de ferro. O ferro tem uma técnica específica, desenvolvida durante esse período da modernidade. Ela condensa imensas quantidades de peso, abrindo espaço interior - antes do ferro, edifícios de uma certa altura precisavam de enormes paredes de pedra e grossas colunas internas para suportar esse peso, fechando o espaço -, para introduzir uma nova experiência sensorial da paisagem em Florianópolis. Apresentando-se como o novo e opondo-se às formas anteriores que organizaram a vida e a paisagem cotidiana - como os amontoados de pedras na região da Rita Maria ou as ilhotas ao redor, como a extinta ilha do carvão -, a infraestrutura participa da estética e de todos os modos de desejo, significado e fantasia que a envolvem. É também a maneira tátil de viver um novo modo de capital

\footnotetext{
${ }^{28}$ LARKIN, Brian. FROM THE SERIES: The Infrastructure Toolbox. By Brian Larkin September 24, 2015. Publication Information.
} 


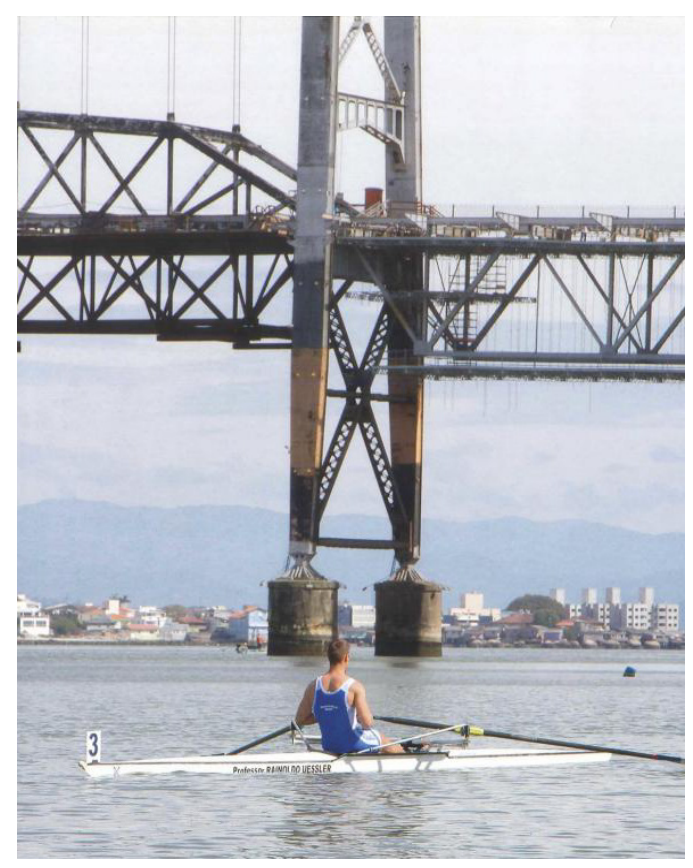

Imagem $\mathbf{N}^{0}$ 29: Remador solitário (Acervo do Clube Náutico Riachuelo)

\section{REFERÊNCIAS}

BENJAMIN, Walter. Passagens de Walter Benjamin. TIEDEMANN, Rolf; BOLLE, Willi; MATOS, Olgária Chaim Feres (Org.). Trad. Irene Aron e Cleonice P. B. Mourão. Belo Horizonte: UFMG/Imprensa Oficial de São Paulo, 2006.

BOURDIEU, Pierre. 1983. Questões de sociologia. Rio de Janeiro: Marco Zero. p 136-153.

CARROLL, Lewis. Através do Espelho e o que Alice encontrou por lá. Ilustrações de John Tenniel e Tradução: Maria Luiza X. de A. Borges. Rio de Janeiro: Zahar, 2009.

CANDAU, Joel. Antropologia de La Memoria. Buenos Aires: Nueva Visión, 2002.

CUNHA,G.S.: Considerações sobre o aterro de Florianópolis, 2005. 10 f. Trabalho de conclusão de Curso (graduação) - Universidade Federal de Santa Catarina.

FERREIRA, Sérgio Luiz. O banho de mar na ilha de Santa Catarina. Florianópolis: Ed. Das Águas, 1998: 59.

LARKIN, Brian. The Politics and Poetics of Infrastructure. Barnard College, Columbia University, New York, NY 10027-6598; email: bl190@columbia.edu

LARKIN, Brian. FROM THE SERIES: The Infrastructure Toolbox. By Brian Larkin 
September 24, 2015. Publication Information.

NECKEL, R. Op Cit., 2003. p.54. KUPKA, Roselane Neckel. Tensões e imagens do viver urbano em Florianópolis - 1910/1930. Dissertação (Mestrado em História), CFH, UFSC, Florianópolis, 1993.; NECKEL, R. Op. Cit., 2003.

NECKEL, Roselane. A República em Santa Catarina: Modernidade e exclusão (1889-1920). Florianópolis: Ed. da UFSC, 2003. p.54.

SEVERI, Carlo. (2007), Le principe de la chimère. Paris, Rue d'Ulm/Musée du quai Branly. \& HANKS, William. (2014), "Translating worlds: the epistemological space of translation". HAU - Journal of Ethnographic Theory, 4 (2): 1-16.

SAHLINS, Marshall. Ilhas de História. Jorge Zahar Editor Rio de Janeiro, 1999.

SCHWARCZ, Lilia. Lendo e agenciando imagens: o rei, a natureza e seus belos naturais. Sociologia e Antropologia, Rio de janeiro, v.04.02: 391 - 431, outubro, 2014.

SARTORI, Carina. Na alvorada de um sport: o remo na ilha de Santa Catarina. 2003. Dissertação Mestrado, Universidade Federal de Santa Catarina, Centro de Filosofia e Ciências Humanas - Programa de pós-graduação em História.

Recebido: $07 / 02 / 2020$

Aprovado: 15/07/2020 